\title{
Kinetics and Mechanism of Oxidation of Hydroxyurea Derivatives with Hexacyanoferrate(III) in Aqueous Solution ${ }^{\dagger}$
}

\author{
Ana Budimir, Tin Weitner, Ivan Kos, Davor Šakić, ${ }^{\ddagger}$ Mario Gabričević, \\ Erim Bešić, and Mladen Biruš*
}

University of Zagreb, Faculty of Pharmacy and Biochemistry, A. Kovačića 1, 10000 Zagreb, Croatia

RECEIVED NOVEMBER 17, 2010; REVISED JANUARY 4, 2011; ACCEPTED JANUARY 20, 2011

\begin{abstract}
Kinetics and mechanisms of the oxidation of methoxyurea and $\mathrm{N}$-methylhydroxyurea were studied in neutral and basic aqueous solutions. The obtained $\mathrm{pH}$ dependences of the oxidation rates indicate that for both hydroxyureas the reactive species are the deprotonated ones. The second order rate constants, the activation enthalpies and the activation entropies for the reactions of methoxyurea $(O$-methylhydroxyurea) and $N$-methylhydroxyurea anions with $\mathrm{Fe}(\mathrm{CN})_{6}{ }^{3-}$ at $25{ }^{\circ} \mathrm{C}, I=2 \mathrm{~mol} \mathrm{dm}^{-3}\left(\mathrm{NaClO}_{4}\right)$ were determined as $(5.06 \pm 0.01) \times 10^{2} \mathrm{~mol}^{-1} \mathrm{dm}^{3} \mathrm{~s}^{-1},(1.92 \pm 0.02) \times 10^{4} \mathrm{~mol}^{-1} \mathrm{dm}^{3} \mathrm{~s}^{-1}, 27 \pm 1 \mathrm{~kJ} \mathrm{~mol}^{-1}$, $16 \pm 1 \mathrm{~kJ} \mathrm{~mol}^{-1},-101 \pm 2 \mathrm{~J} \mathrm{~mol}^{-1} \mathrm{~K}^{-1}$, and $-107 \pm 4 \mathrm{~J} \mathrm{~mol}^{-1} \mathrm{~K}^{-1}$, respectively. The $\mathrm{p} K_{\mathrm{a}}$ value of methoxyurea at $25^{\circ} \mathrm{C}$ and $2 \mathrm{~mol} \mathrm{dm}^{-3}$ ionic strength was determined kinetically as $12.7 \pm 0.1$ and the thermodynamic parameters for the deprotonation reaction were determined as $\Delta_{\mathrm{a}} H=43 \pm 1 \mathrm{~kJ} \mathrm{~mol}^{-1}$, and $\Delta_{\mathrm{a}} S=-96 \pm 4 \mathrm{~J} \mathrm{~mol}^{-1} \mathrm{~K}^{-1}$. When the kinetic results are compared with the data reported for hydroxyurea, an inverse dependence of the rate constants on the $\mathrm{p} K_{\mathrm{a}}$ of the hydroxyurea derivatives at $25^{\circ} \mathrm{C}$ is observed. Such unexpected behaviour has been explained by the ab initio calculations and NBO analysis of HOMOs for all three hydroxyureates. (doi: 10.5562/cca1799)
\end{abstract}

Keywords: methoxyurea, $\mathrm{N}$-methylhydroxyurea, hexacyanoferrate, oxidation, kinetics, NBO, quantum chemical study

\section{INTRODUCTION}

Hydroxyurea (HU) (Chart 1) is a highly specific low molecular weight inhibitor of ribonucleotide reductase, and, therefore, of DNA synthesis, ${ }^{1}$ with a broad spectrum of anti-tumor effects, ${ }^{2}$ which also effectively improves clinical outcomes in patients with sickle cell disease. $^{3,4}$

Hydroxyureas belong to the family of hydroxamic acids that may act as nitric-oxide donors under oxidative conditions in vitro. ${ }^{5,6}$ In reactions with hemoglobin, myoglobin, or hemin, NO may contribute to the overall<smiles>[R]ON([R])C(N)=O</smiles>

Chart 1. Structures of hydroxyureas: hydroxyurea (HU): $\mathrm{R}^{1}=$ $\mathrm{R}^{2}=\mathrm{H}, \mathrm{N}$-methylhydroxyurea (NMHU): $\mathrm{R}^{1}=\mathrm{CH}_{3}, \mathrm{R}^{2}=\mathrm{H}$, and $N$-methoxyurea (MetU): $\mathrm{R}^{1}=\mathrm{H}, \mathrm{R}^{2}=\mathrm{CH}_{3}$ pathophysiological properties of HU. ${ }^{7}$ It was shown that the formation of iron nitrosyl hemoglobin from the reaction of hydroxyureas and hemoglobin requires an unsubstituted $-\mathrm{NHOH}$ group and that the nitrogen atom of the non- $N$-hydroxy group must contain at least a single hydrogen atom. ${ }^{8}$ It was also reported that the selected hydroxyureas are oxidized by lipoxygenase to form their corresponding nitroxides. ${ }^{9}$

On the other hand, investigation of inhibitory effects of nitro-vasodilators and HU on DNA synthesis in cultured human aortic smooth muscle cells indicates that $\mathrm{NO}$ does not mediate the inhibitory action of $\mathrm{HU}$ in this system. ${ }^{10}$ In line with that observation, we have recently published papers dealing with the oxidation of $\mathrm{HU}$ by dioxovanadium $(\mathrm{V})$ and $\mathrm{Fe}(\mathrm{CN})_{6}^{3-}$ ions, which have revealed that the oxidation of $\mathrm{HU}$ with those two oxidizing agents does not afford the formation of NO. ${ }^{11,12}$ These studies are extended in this work by the investigation of the reaction mechanism of reduction of the $\mathrm{Fe}(\mathrm{CN})_{6}{ }^{3-}$ ion $^{13}$ with two derivatives of hydroxyurea shown in the Chart 1, viz. $N$-methylhydroxyurea

\footnotetext{
$\dagger$ This article belongs to the Special Issue Chemistry of Living Systems devoted to the intersection of chemistry with life.

$\$$ Taken in part from Davor Šakić's PhD Thesis.

* Author to whom correspondence should be addressed. (E-mail: birus@pharma.hr)
} 
(NMHU) and methoxyurea (MetU).

The hydroxamic acids contain the smallest $\mathrm{O}=\mathrm{CNH}$ unit that can bind to the DNA helix, ${ }^{14,15}$ and the observed biological activities of hydroxamic acids might be related to the similarity between the $\mathrm{O}=\mathrm{CNH}$ unit and analogous structural segments found in proteins. ${ }^{16}$ Hence, knowledge of the favoured ionization sites is important for understanding the role played by hydroxamic acids in biological processes, but also in metal ion complexation, since these processes could be interrelated. A large number of papers dealing with theoretical and experimental aspects of hydroxamic acids' acidity have been published, ${ }^{17}$ among which we have recently published a thermodynamic study of the acid-base properties of $\mathrm{HU}$ and NMHU. ${ }^{18}$ It was concluded that the electronic properties of the functional groups, $R_{1}$ and $R_{2}$, play a significant role in the ionization of hydroxamic acids, ${ }^{19}$ but an unresolved dispute whether hydroxamic acids in water deprotonate at the oxygen or the nitrogen atom of hydroxamic moiety is still open for debate.

Since the redox active species of hydroxyureas are found to be their anions, and the $\mathrm{p} K_{\mathrm{a}}$ values of hydroxyureas are necessary for interpretation of the redox kinetics, herein we also report determination of the ionization constant of MetU. In order to confirm the identity of the favoured ionization site in $\mathrm{MetU}\left(-\mathrm{NH}_{2}\right.$ or $\left.-\mathrm{NHOCH}_{3}\right)$, we also report the quantum chemical calculations of its electronic structures and energies. Thus, besides improving our understanding of the reaction mechanism of oxidation of the hydroxyurea derivatives, this work also advances understanding of the acid-base properties of hydroxamic acids in general, presenting our contribution to answer the above question by studying MetU molecule that has no $-\mathrm{OH}$ site available for deprotonation.

\section{EXPERIMENTAL}

\section{Materials}

All chemicals used were commercially available, of reagent grade and were used without further purification. All water used was deionized and then twice distilled in an all-glass apparatus, first from an alkaline solution of $\mathrm{KMnO}_{4}$. All solutions were prepared with twice distilled and deionized water boiled for 1 hour and cooled down under argon atmosphere (purified by a SIGMA OXICLEAR cartridge) in order to exclude $\mathrm{CO}_{2}$ and $\mathrm{O}_{2} . \mathrm{NaClO}_{4}$ was synthesized by addition of $\mathrm{HClO}_{4}$ to a water solution of $\mathrm{NaHCO}_{3}$ until neutralized, then filtered and recrystallized. A $7.2 \mathrm{~mol} \mathrm{dm}$ stock solution of $\mathrm{NaClO}_{4}$ was standardized by passage through Amberlite IR120 strong acid cation exchange column in the $\mathrm{H}^{+}$ form, and titrated against standard $\mathrm{NaOH}$. In all meas- urements buffered solutions of $\mathrm{K}_{3}\left[\mathrm{Fe}(\mathrm{CN})_{6}\right]$ and NMHU were prepared by addition of appropriate volumes of stock solutions of metal or ligand and buffer, except in measurements with HEPES because of a slow reaction of HEPES and $\mathrm{K}_{3}\left[\mathrm{Fe}(\mathrm{CN})_{6}\right]$ observed by a yellowish colour of $\mathrm{K}_{3}\left[\mathrm{Fe}(\mathrm{CN})_{6}\right]$ disappearing within a few hours (depending on the concentration of $\left.\mathrm{K}_{3}\left[\mathrm{Fe}(\mathrm{CN})_{6}\right]\right)$. These solutions were prepared by the addition of double amounts of buffer to NMHU solutions. In all solutions $\mathrm{pH}$ was adjusted by the addition of a standard $\mathrm{NaOH}$ solution. The ionic strength was maintained constant with $\mathrm{NaClO}_{4}$. Care was taken in the preparation and manipulation of hexacyanoferrate(III) solutions in order to prevent decomposition upon light exposure and long standing. Fresh solutions of hexacyanoferrate(III) were prepared before each experiment and their concentrations were calculated using the molar absorptivity of $1050 \mathrm{~mol}^{-1} \mathrm{dm}^{-3} \mathrm{~cm}^{-1}$ at $420 \mathrm{~nm}$.

\section{Synthesis of Hydroxyureas}

NMHU was prepared by drop wise addition of $5.125 \mathrm{~g}$ $\mathrm{KCNO}(0.063 \mathrm{~mol})$ dissolved in $50 \mathrm{ml}$ water to solution of $5.25 \mathrm{~g}(0.063 \mathrm{~mol}) \mathrm{N}$-methyl hydroxylamine hydrochloride dissolved in $50 \mathrm{ml}$ of methanol. The solution was mixed over night at room temperature and the solvent was removed under reduced pressure afterwards. The remaining oil was dissolved in diethyl-ether and filtered to remove $\mathrm{KCl}$. Diethyl-ether was then removed under reduced pressure and the remaining oily substance began to crystallize in a vacuum desiccator over $\mathrm{P}_{2} \mathrm{O}_{5}$. Crystallization and filtration from ethylacetate gave the pure product (yield $4.465 \mathrm{~g}, 79 \%,{ }^{1} \mathrm{H}-\mathrm{NMR}$ (DMSO-d ${ }_{6}$ ) $\delta /$ ppm: 9.27, 6.27 and $2.95 ;{ }^{13} \mathrm{C}-\mathrm{NMR}$ (DMSO-d ${ }_{6}$ ) $\delta / \mathrm{ppm}: 162.45$ and 38.26). Methoxyurea was prepared according to published procedure and was checked for purity by its melting point $\left(81-84{ }^{\circ} \mathrm{C}\right.$, lit. value: $\left.84{ }^{\circ} \mathrm{C}\right)^{20}$ and spectroscopic data: IR $(\mathrm{KBr}) v / \mathrm{cm}^{-1}$ : 3402, 3220, 2170, 1670, 1598, 1474, 1440, 1416, 1194 , $1128,1092,810,712,602,564 ;{ }^{1} \mathrm{H}$ NMR (DMSO-d ${ }_{6}$ )

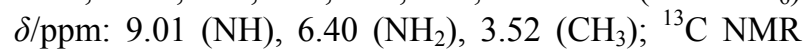
$\left(\mathrm{DMSO}_{\mathrm{d}}\right) \delta / \mathrm{ppm}$ : $161.82(\mathrm{C}=\mathrm{O}), 64.40\left(\mathrm{CH}_{3}\right)$.

\section{Instrumental Measurements}

The UV-Vis absorption spectra were recorded on a VARIAN CARY 50 spectrophotometer. Kinetic measurements were performed by using an OLIS USA RSM 1000 stopped-flow spectrophotometer coupled to an online data acquisition system and equipped with thermostatted cell compartment. The kinetic traces were evaluated using the OlIS GLOBALWORKS ${ }^{\mathrm{TM}}$ program. Temperature control was maintained with the use of a HAAKE DC10-K10 refrigerated circulator bath with temperature accuracy of $0.1{ }^{\circ} \mathrm{C}$ over the range $10-100{ }^{\circ} \mathrm{C}$. Absorbance changes during the kinetics were followed 
at $420 \mathrm{~nm}$, and each experimental rate constant reported herein is an average of at least 5 runs carried out. $\mathrm{pH}$ was measured using Mettler Toledo MP220 pH-meter with InLab 413 combination electrode. Differences in $\mathrm{pH}$ values before and after reaction were negligible. The electron paramagnetic resonance (EPR) spectra were recorded at room temperature with a Bruker Elexsys E500 X-band spectrometer for both aqueous and heavywater solutions. The spectra were recorded immediately after mixing $\mathrm{Fe}(\mathrm{CN})_{6}{ }^{3-}$ with NMHU.

\section{Computational Details}

The Gaussian 09 program package ${ }^{21}$ has been employed in all the calculations. Initial geometries and their different rotamers were built using Avogadro program package. ${ }^{22}$ Initial geometries of the water clusters of MetU species were generated by stochastic search procedure, namely a modified Saunder's kick procedure, ${ }^{23}$ including two important modifications: $(i)$ use of dynamic molecular fragments (viz. water molecules) that are randomly rotated, and then kicked around a stationary molecular fragment (viz. the MetU species), versus the original all-atom displacement approach (Addicoat and Metha ${ }^{24}$ also made the same modification), and (ii) constraint of the kick relative to the position of randomly selected atom of stationary molecular fragment, thus avoiding the necessity to define a box in which the kick is allowed. In other words, defining the "kick-size" and "box-size" (e.g. maximum displacement of atom from starting position in specified space as defined by Saunders) is now replaced with a value of maximum displacement of dynamic molecular fragment from a randomly selected atom of the stationary structure. Water molecules were placed randomly in a variety of locations to sample the various arrays of hydrogen-bonding networks available between MetU/water and water/water molecules, reducing the possible errors caused by the limitations of our "chemical intuition".

Batches of initial geometries were prepared, each consisting of at least 100 different starting geometries. At least three batches of every investigated cluster were submitted for first optimization using the Becke three parameter Hybrid functionals with Lee-Yang-Parr correlation method ${ }^{25}$ with Pople's $6-31+\mathrm{G}(\mathrm{d})$ basis set $^{26}$ (B3LYP/6-31+G(d)) without any conformational or symmetry constraints. The five lowest-energy distinct minima from each batch were compared and if no new original minima were found it was assumed that a global minimum had been found. Otherwise, if a new distinct minimum with lowest energy was found, a new batch was created and submitted in the same way. The claim of the found global minimum was further tested by a hand-modification of geometries while the nature of the stationary point was verified by computations of the harmonic frequencies at the same levels of theory.

Solvent effects in water have been calculated by means of the polarized continuum model with polarisable conductor parameters $(\mathrm{CPCM})^{27}$ in which the solvent is considered as a continuum dielectric, characterized by a constant permittivity. The CPCM method was directly applied to the neutral and anionic forms of MetU, as implemented in the Gaussian 09 package, using the same level of theory. The cavity radii were those recommended for the UAHF model. ${ }^{28}$ The relative solvent dielectric constant at $298.15 \mathrm{~K}$ has been set at 78.5 (Gaussian 09 default for water). Thus obtained minima were then optimized at B2PLYP/6-311+ $\mathrm{G}(\mathrm{d}, \mathrm{p}),{ }^{29} \mathrm{MP} 2 / 6-311+\mathrm{G}(\mathrm{d}, \mathrm{p})^{30}$ and $\mathrm{G} 3 \mathrm{~B} 3^{31}$ methods with hydration effects calculated by the CPCM method on the same levels of theory, except for G3B3, where the hydration energy was computed on B3LYP/6$311++\mathrm{G}(\mathrm{d}, \mathrm{p})$ level of theory. B3LYP was selected as the most frequently used density functional theory which has good concurrence with experimental results and is a fairly cheap and fast method for large sets of starting structures. MP2 method was selected as the most used Møller-Plesset method, and B2PLYP was used as a representative of the double hybrid method which combines exact HF exchange with an MP2-like correlation to a DFT calculation. G3B3 method involves complex energy computations including several predefined calculations on the specified molecular system and is the most expensive in computer clock-time.

Natural Bond Analysis ${ }^{32}$ was performed to determine charge distribution and molecular orbital composition and shape, using NBO version 3, as implemented in Gaussian 09 program package. For visualization of orbitals Avogadro program package was used.

\section{RESULTS}

\section{General Observations}

After mixing the reactants in an aqueous solution within a few milliseconds mixing time, a spectral maximum at $420 \mathrm{~nm}$, where only $\mathrm{Fe}(\mathrm{CN})_{6}{ }^{3-}$ absorbs the light, fades out on stopped-flow time scale. The first recorded UVVis spectrum of the reaction mixture corresponded to $\mathrm{Fe}(\mathrm{CN})_{6}{ }^{3-}$, whereas the spectrum measured after the reaction was completed corresponded to $\mathrm{Fe}(\mathrm{CN})_{6}{ }^{4-}$ (Figure S1). Since on that time-scale $\left[\mathrm{Fe}(\mathrm{CN})_{6}\right]^{3-}$ does not undergo the observable aquation reaction, ${ }^{33}$ the observed colour fading can be attributed to the reduction of $\mathrm{Fe}(\mathrm{CN})_{6}{ }^{3-}$ with hydroxyureas. A single exponential decay Eq. (1) of the measured absorbance vs. time (Figure 1) was successfully fitted to the experimental data ( $\triangle A$ is the total absorbance change while $A_{t}$ and $A_{\text {inf. }}$ are the absorbance at time $t$ and infinite time, respectively) implying first-order dependence with respect to the absorbing species (counting here $\mathrm{Fe}(\mathrm{CN})_{6}{ }^{3-}$ and its 


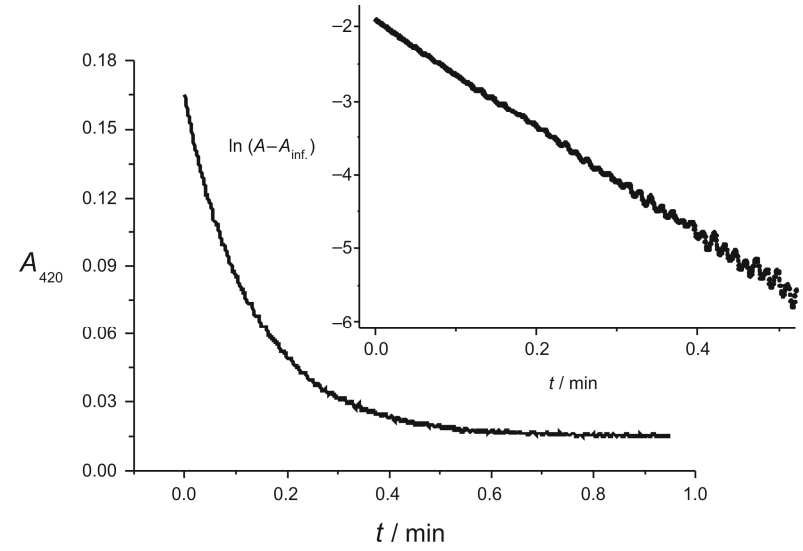

Figure 1. A typical kinetic trace of reaction between $\mathrm{Fe}(\mathrm{CN})_{6}{ }^{3-}$ and NMHU followed at $\lambda=420 \mathrm{~nm}$. Conditions: $c\left(\mathrm{~K}_{3} \mathrm{Fe}(\mathrm{CN})_{6}\right)=0.5 \mathrm{mmol} \mathrm{dm}{ }^{-3}, c(\mathrm{NMHU})=2 \cdot 10^{-2} \mathrm{~mol}$ $\mathrm{dm}^{-3}, \mathrm{pH}=8, c($ HEPES $)=0.2 \mathrm{~mol} \mathrm{dm}^{-3}, I=2 \mathrm{~mol} \mathrm{dm}^{-3}, \theta=$ $(25 \pm 0.2){ }^{\circ} \mathrm{C}$. Inset: the linear dependence of $\ln \left(A-A_{\text {inf. }}\right) v s$. time confirming the first-order condition.

outer-sphere ion-pairs).

$$
A_{t}=\Delta A \exp \left(-k_{\text {obs }} t\right)+A_{\text {inf. }}
$$

In experiments dealing with NMHU buffer solutions were prepared from MES and HEPES to cover the whole investigated $\mathrm{pH}$ range. No significant buffer concentration dependence of $k_{\mathrm{obs}}$ was observed (Figure S2).

\section{Stoichiometry of the Redox Reactions}

Mixtures having increasing hydroxyureas: $\mathrm{Fe}(\mathrm{CN})_{6}{ }^{3-}$ molar ratios were allowed to react to completion, and the reaction stoichiometries were determined spectrophotometrically by measuring the $420 \mathrm{~nm}$ absorbance of reaction solutions due to unreacted Fe(III) species.

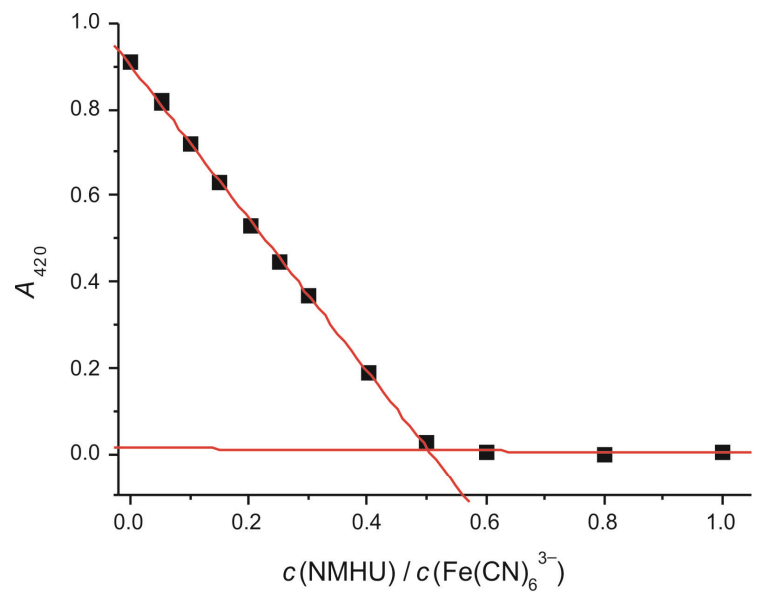

Plots of absorbance against the mixing ratio first showed a linear decrease and then constant values describing a horizontal line. From the intersection of straight lines shown in Figure 2, the stoichiometric molarity ratio for NMHU (like for $\mathrm{HU})^{12}$ is found to be $1: 2=\mathrm{NMHU}: \mathrm{Fe}(\mathrm{CN})_{6}{ }^{3-}$, whereas for MetU the found ratio is $1: 1$. These results indicate that, contrary to $\mathrm{HU}$ and NMHU, which act as two-electron donors, MetU acts as a one-electron donor in the reduction of $\mathrm{Fe}(\mathrm{CN})_{6}{ }^{3-}$.

\section{Free Radical Formation}

EPR spectra of a free radical formed in the reaction of $\mathrm{Fe}(\mathrm{CN})_{6}{ }^{3-}$ with $\mathrm{NMHU}$ in water and $\mathrm{D}_{2} \mathrm{O}$ were found to be identical to the analogous spectra recorded when NMHU was oxidized with dioxovanadium(V). ${ }^{34}$ An attempt to record a free radical generated from MetU in reaction with $\mathrm{Fe}(\mathrm{CN})_{6}{ }^{3-}$ at room temperature by the EPR spectroscopy technique failed, most probably due to a too low concentration of the formed free radical. Therefore, involvement of a free radical in that reaction was assessed by initiating the polymerization of acrylamide: $0.09 \mathrm{~g} \mathrm{MetU}, 0.033 \mathrm{~g} \mathrm{~K}_{3} \mathrm{Fe}(\mathrm{CN})_{6}$ and $0.39 \mathrm{~g}$ of acrylamide were placed in a dry test tube and dearated with Ar for 15 minutes. The test tube was sealed and 5 $\mathrm{ml}$ of degassed water was added with a syringe and stirred for $10 \mathrm{~min}$. This reaction mixture was added to a double volume of cold methanol with the result of progressive formation of a white solid across the whole solution. When the experiment was repeated in the absence of MetU or $\mathrm{K}_{3} \mathrm{Fe}(\mathrm{CN})_{6}$ under the same conditions no white solid was formed.

\section{Kinetics of oxidation}

As mentioned above, the kinetics of the redox reaction

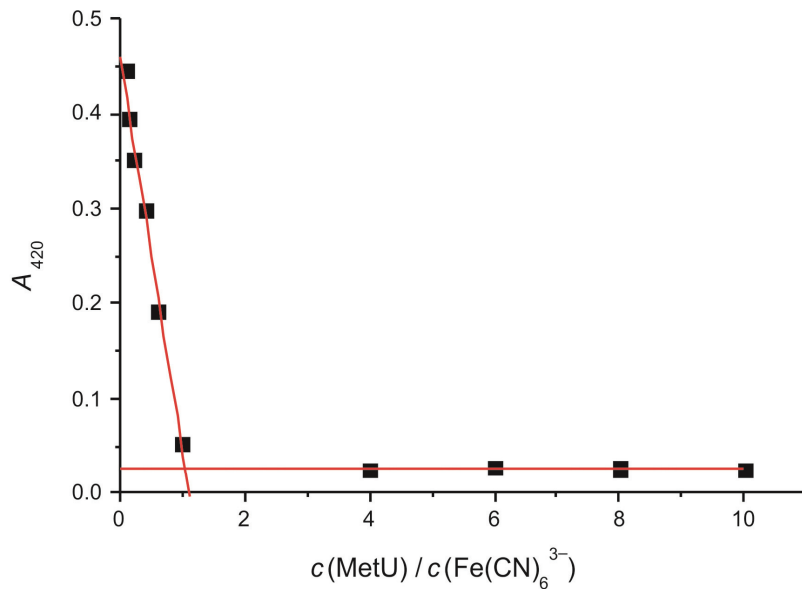

Figure 2. Absorbance of the solutions equilibrated at $(25 \pm 0.1){ }^{\circ} \mathrm{C}$ of (left) $\mathrm{NMHU}$ and $\mathrm{K}_{3} \mathrm{Fe}(\mathrm{CN})_{6}$ as a function of $\mathrm{NMHU} / \mathrm{Fe}(\mathrm{CN})_{6}{ }^{3-}$ molar ratio. Conditions: $c\left(\mathrm{~K}_{3} \mathrm{Fe}(\mathrm{CN})_{6}\right)=1 \mathrm{mmol} \mathrm{dm}{ }^{-3}, 0.1 \mathrm{~mol} \mathrm{dm}{ }^{-3} \mathrm{NaOH}, I=2 \mathrm{~mol} \mathrm{dm}^{-3}\left(\mathrm{NaClO}_{4}\right), l=1$ $\mathrm{cm}$, and (right) $\mathrm{MetU}$ and $\mathrm{K}_{3} \mathrm{Fe}(\mathrm{CN})_{6}$ at $420 \mathrm{~nm}$ as a function of $\mathrm{MetU} / \mathrm{Fe}(\mathrm{CN})_{6}{ }^{3-}$ molar ratio. Conditions: $c\left(\mathrm{~K}_{3} \mathrm{Fe}(\mathrm{CN})_{6}\right)=0.5$ $\mathrm{mmol} \mathrm{dm}{ }^{-3}, 0.01 \mathrm{~mol} \mathrm{dm}^{-3} \mathrm{NaOH}, I=2 \mathrm{~mol} \mathrm{dm}^{-3}\left(\mathrm{NaClO}_{4}\right), l=1 \mathrm{~cm}$. 

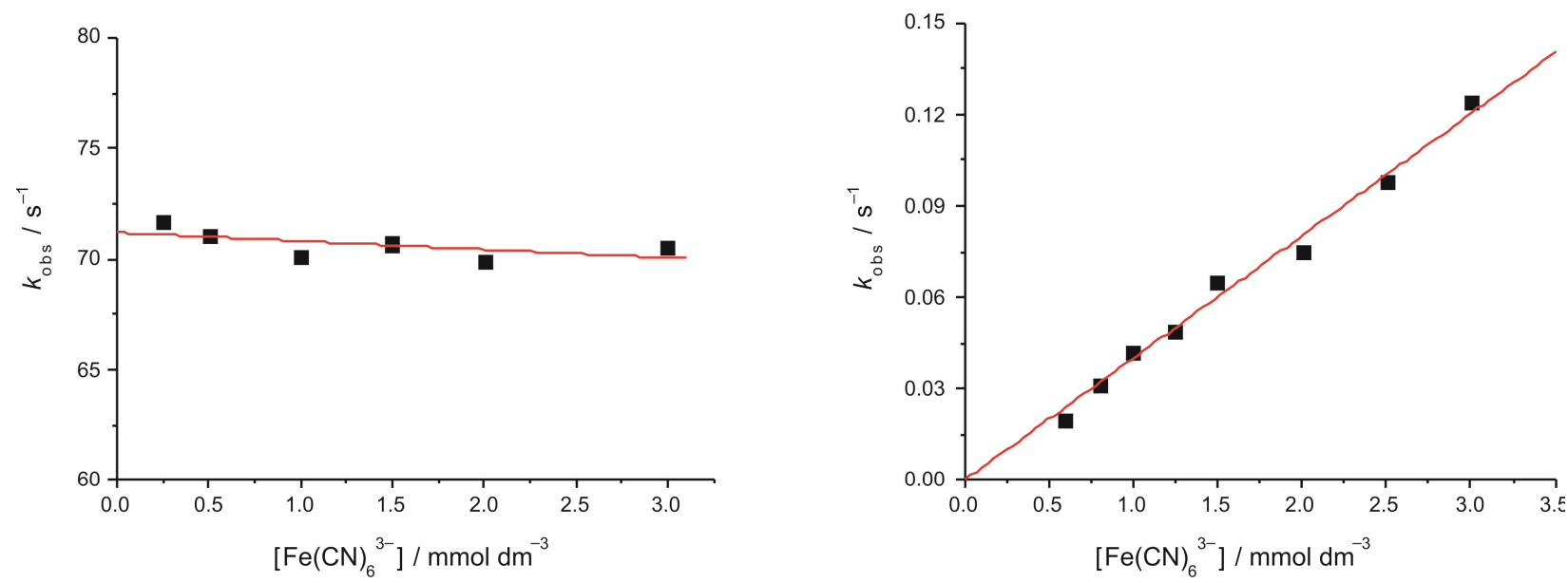

Figure 3. Plots of $k_{\text {obs }} v s$. initial $\left[\mathrm{K}_{3} \mathrm{Fe}(\mathrm{CN})_{6}\right]$ for redox reaction between $\mathrm{Fe}(\mathrm{CN})_{6}{ }^{3-}$ and hydroxyurea derivatives. (left) NMHU in a molar excess over $\mathrm{Fe}(\mathrm{CN})_{6}{ }^{3-}$ at $\mathrm{pH}=10$. Conditions: $c(\mathrm{NMHU})=0.03 \mathrm{~mol} \mathrm{dm}{ }^{-3}, c$ (buffer $)=0.2 \mathrm{~mol} \mathrm{dm}^{-3}, I=2 \mathrm{~mol} \mathrm{dm}^{-3}, \theta=$ $(25 \pm 0.2)^{\circ} \mathrm{C}$ and (right) $\mathrm{Fe}(\mathrm{CN})_{6}{ }^{3-}$ in a molar excess over MetU at $\mathrm{pH}=12$. Conditions: $c(\mathrm{MetU})=0.03 \mathrm{mmol} \mathrm{dm}{ }^{-3}, I=2 \mathrm{~mol}$ $\mathrm{dm}^{-3}\left(\mathrm{NaClO}_{4}\right), \theta=(25 \pm 0.2)^{\circ} \mathrm{C}$.

between $\mathrm{Fe}(\mathrm{CN})_{6}{ }^{3-}$ and hydroxyureas were studied using the stopped-flow technique, monitoring a decrease in absorbance of $\mathrm{Fe}(\mathrm{CN})_{6}{ }^{3-}$ at $420 \mathrm{~nm}$ with time (under the pseudo-first order conditions and constant ionic strength) to which the expression (1) was fitted. ${ }^{35}$ If an inner-sphere species had been created, a bathocromic shift of the absorption band, associated with the ligandmetal charge transfer, could have been expected. An absence of such a shift in the final UV-Vis spectrum, which coincides with spectrum of $\mathrm{Fe}(\mathrm{CN})_{6}{ }^{4-}$, proves that this is the reduction product.

\section{Effect of the Initial $\mathrm{Fe}(\mathrm{CN})_{6}{ }^{3-}$ Concentration}

In order to determine the rate order with respect to hexacyanoferrate(III) concentration, two series of kinetic measurements were carried out in which only the initial concentration of $\mathrm{K}_{3} \mathrm{Fe}(\mathrm{CN})_{6}$ was varied. In the first series
$\mathrm{Fe}(\mathrm{CN})_{6}{ }^{3-}$ was in molar excess over hydroxyurea derivatives and in the second series the ratio was reversed. In the latter case the obtained pseudo-first order rate constants are independent of the $\mathrm{Fe}(\mathrm{CN})_{6}{ }^{3-}$ concentration, while in the former case they exhibit a linear dependence on the initial $\mathrm{Fe}(\mathrm{CN})_{6}{ }^{3-}$ concentration (Figure 3). These facts clearly demonstrate the first order dependence of the redox reactions with respect to the concentration of this reactant.

Effect of the Initial Concentration of Hydroxyureas With the hydroxyurea derivatives in a large molar excess over $\mathrm{Fe}(\mathrm{CN})_{6}{ }^{3-}$, linear dependencies of the calculated pseudo-first order rate constants, $k_{\text {obs }}$, on the concentration of both hydroxyureas were observed (Figure 4). The slopes at two different proton concentrations differ significantly. The larger slopes at the higher base con-
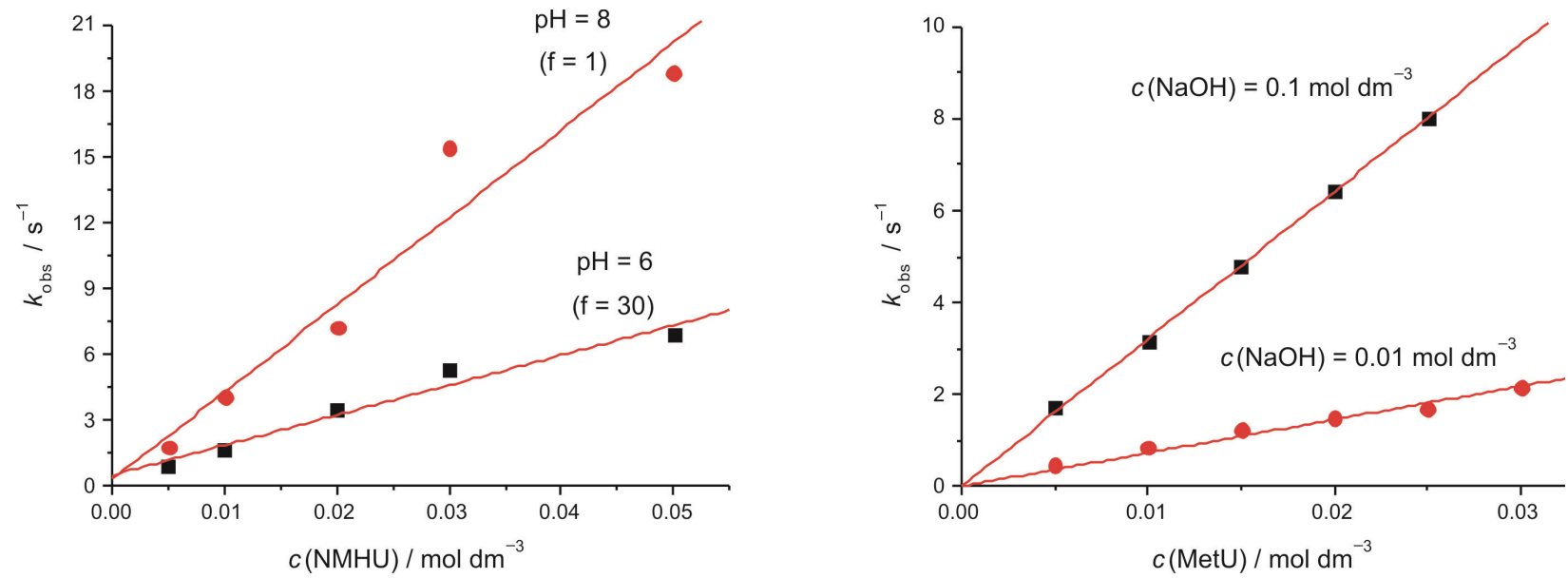

Figure 4. Dependence of $k_{\mathrm{obs}}$ of oxidation of hydroxyurea derivative on its concentration. (left) Conditions: $c\left(\mathrm{~K}_{3} \mathrm{Fe}(\mathrm{CN})_{6}\right)=0.5$ mmol dm ${ }^{-3}, c$ (buffer) $=0.2 \mathrm{~mol} \mathrm{dm}^{-3}, I=2 \mathrm{~mol} \mathrm{dm}^{-3}\left(\mathrm{NaClO}_{4}\right), \theta=(25 \pm 0.1)^{\circ} \mathrm{C}$. (right) Conditions: $c\left(\mathrm{~K}_{3} \mathrm{Fe}(\mathrm{CN})_{6}\right)=0.25 \mathrm{mmol}$ $\mathrm{dm}^{-3}, I=2 \mathrm{~mol} \mathrm{dm}^{-3}\left(\mathrm{NaClO}_{4}\right), \theta=(25 \pm 0.1)^{\circ} \mathrm{C}$. 

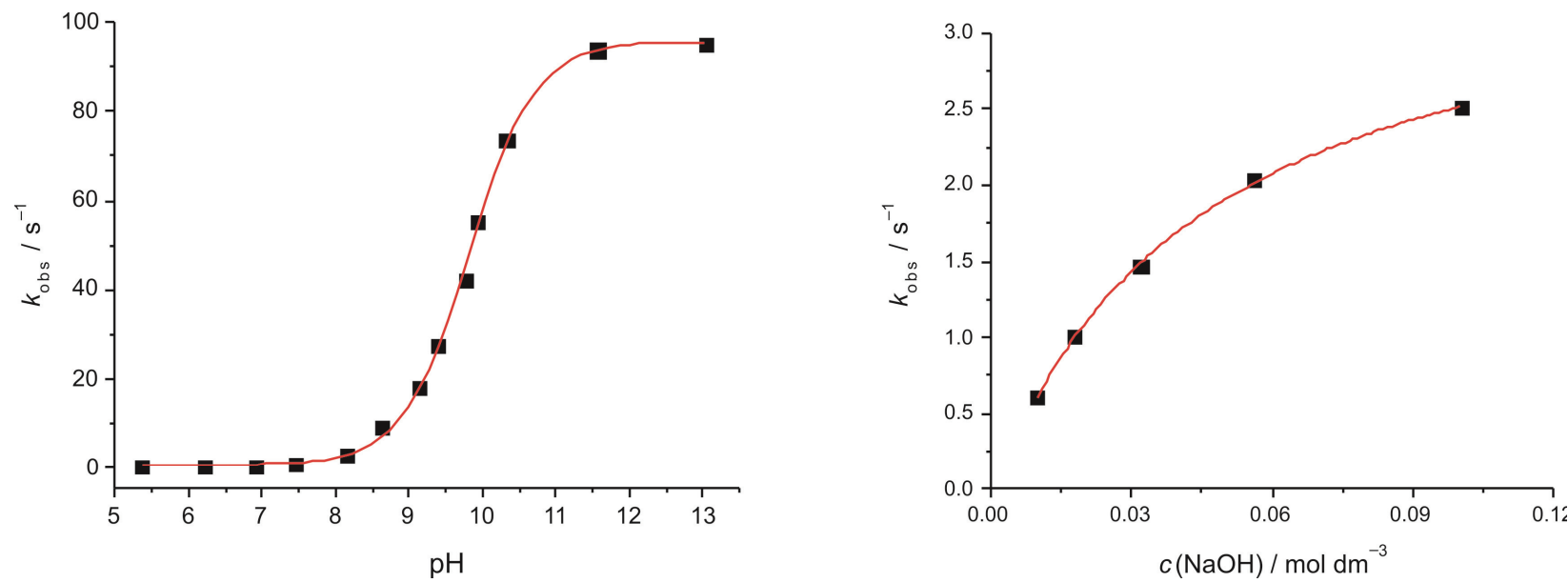

Figure 5. Dependence of the observed pseudo-first order rate constants $\left(k_{\mathrm{obs}}\right)$ on the acidity of aqueous solutions. (left) Conditions: $\mathrm{c}(\mathrm{NMHU})=5 \mathrm{mmol} \mathrm{dm}{ }^{-3}, c\left(\mathrm{~K}_{3} \mathrm{Fe}(\mathrm{CN})_{6}\right)=0.2 \mathrm{mmol} \mathrm{dm}^{-3}, c$ (buffer $)=50 \mathrm{mmol} \mathrm{dm}{ }^{-3}, I=2 \mathrm{~mol} \mathrm{dm}^{-3}\left(\mathrm{NaClO}_{4}\right), \theta=(25 \pm 0.1)^{\circ} \mathrm{C}$. (right) Conditions: $c(\mathrm{MetU})=7.5 \mathrm{mmol} \mathrm{dm}^{-3}, c\left(\mathrm{~K}_{3} \mathrm{Fe}(\mathrm{CN})_{6}\right)=0.25 \mathrm{mmol} \mathrm{dm}^{-3}, I=2 \mathrm{~mol} \mathrm{dm}^{-3}\left(\mathrm{NaClO}_{4}\right), \theta=(25 \pm 0.1)^{\circ} \mathrm{C}$.

centration are indicative of a more reactive anionic species in comparison with the molecular forms. Hence, the dependence of the oxidation rates on the acidity of the aqueous solution was studied with the reductants in a large molar excess over hexacyanoferrate.

As shown in Figure 5 (left), a sigmoid dependence was obtained for NMHU, which can be expressed by equation (2),

$$
k_{\mathrm{obs}}=\left(k_{1}\left[\mathrm{H}^{+}\right]+k_{2} K_{\mathrm{a}}\right)[\mathrm{NMHU}]_{\mathrm{tot}} /\left(\left[\mathrm{H}^{+}\right]+K_{\mathrm{a}}\right)
$$

where $k_{\text {obs }}$ is the observed pseudo-first order rate constant, $k_{1}$ is the second order rate constant for the reaction of $\mathrm{Fe}(\mathrm{CN})_{6}{ }^{3-}$ with protonated species of NMHU, $k_{2}$ is the second order rate constant for the reaction of $\mathrm{Fe}(\mathrm{CN})_{6}{ }^{3-}$ with deprotonated species of NMHU, and $K_{\mathrm{a}}$ is the deprotonation equilibrium constant of NMHU (paths assignation according to Scheme 1). Assuming a first order with respect to the NMHU concentration, the calculated values are: $k_{1}=1(1) \times 10^{2} \mathrm{~mol}^{-1} \mathrm{dm}^{3} \mathrm{~s}^{-1}, k_{2}=$ $1.92(2) \times 10^{4} \mathrm{~mol}^{-1} \mathrm{dm}^{3} \mathrm{~s}^{-1}$, and $\mathrm{p} K_{\mathrm{a}}=9.82(2){ }^{36}$ The calculated $\mathrm{p} K_{\mathrm{a}}$ value is very similar to the value determined potentiometrically under the same experimental conditions ( $\mathrm{p} K_{\mathrm{a}}=9.79,{ }^{18} I=2 \mathrm{~mol} \mathrm{dm}^{-3} \mathrm{NaClO}_{4}, \theta=25$ ${ }^{\circ} \mathrm{C}$ ). Because of a large standard deviation obtained for $k_{1}$, the reaction of $\mathrm{Fe}(\mathrm{CN})_{6}{ }^{3-}$ with the protonated species should be considered as rather dubious. Nevertheless, even if the calculated value were considered as an upper limit, $k_{2}$ would be at least three orders of magnitude larger than $k_{1}$. The observed difference can be explained by the build-up of negative charge upon the deprotonation of NMHU.

A nonlinear dependence of $k_{\mathrm{obs}}$ on hydroxide concentration obtained for MetU (Figure 5, right side) can be expressed by equation (3),

$$
k_{\mathrm{obs}}=a\left[\mathrm{OH}^{-}\right] /\left(1+b\left[\mathrm{OH}^{-}\right]\right)
$$

which is equivalent to Eq. (4), i.e. the reduced form of kinetic expression (2).

$$
k_{\mathrm{obs}}=k_{2} K_{\mathrm{a}}[\mathrm{MetU}]_{\mathrm{tot}} /\left(\left[\mathrm{H}^{+}\right]+K_{\mathrm{a}}\right)
$$

The parameters $a$ and $b$ in Eq. (3) equal the ratios $k_{2} K_{\mathrm{a}}[\mathrm{MetU}]_{\mathrm{tot}} / K_{\mathrm{w}}$ and $K_{\mathrm{a}} / K_{\mathrm{w}}$ in Eq. (4), respectively. ${ }^{37}$ Assuming $K_{\mathrm{w}}=1.07 \times 10^{-14}$ at $25^{\circ} \mathrm{C}$ and $I=2 \mathrm{~mol}$ $\mathrm{dm}^{-3}{ }^{38} K_{\mathrm{a}}$ and $k_{2}$ were calculated as $2.14(6) \times 10^{-13}$ $\mathrm{mol}^{-1} \mathrm{dm}^{3}$ and $5.06(1) \times 10^{2} \mathrm{~mol}^{-1} \mathrm{dm}^{3} \mathrm{~s}^{-1}$, respectively. The calculated $K_{\mathrm{a}}$ value of MetU is approximately three orders of magnitude smaller than the $K_{\mathrm{a}}$ values of other two hydroxyureas studied. An attempt to determine the $K_{\mathrm{a}}$ value by the combined $\mathrm{pH}$-spectrophotometric titration failed, most probably due to the $\mathrm{p} K_{\mathrm{a}}$ value outside the range of the glass electrode reliability.

\section{Effect of the Initial $\mathrm{Fe}(\mathrm{CN})_{6}{ }^{4-}$ Concentration}

The effect of the concentration of hexacyanoferrate(II) ions, as one of the reaction products initially added to the reaction solutions, on the rate of the redox reaction was also studied. The concentrations of hexacyanoferrate(II) ions were varied up to $1 \mathrm{mmol} \mathrm{dm}^{-3}$ at fixed concentrations of the hydroxyurea derivatives, $\mathrm{Fe}(\mathrm{CN})_{6}{ }^{3-}$ and $\mathrm{NaOH}$, and at constant ionic strength $I=$ $2 \mathrm{~mol} \mathrm{dm}^{-3}\left(\mathrm{NaClO}_{4}\right)$. The rate remained constant upon changing the concentration of hexacyanoferrate(II) ions, thus ruling out "reversibility" of the rate determining electron-transfer step. The observed dependence of rate constants on the initial concentration of $\mathrm{K}_{4} \mathrm{Fe}(\mathrm{CN})_{6}$ is presented in Figure S3. 


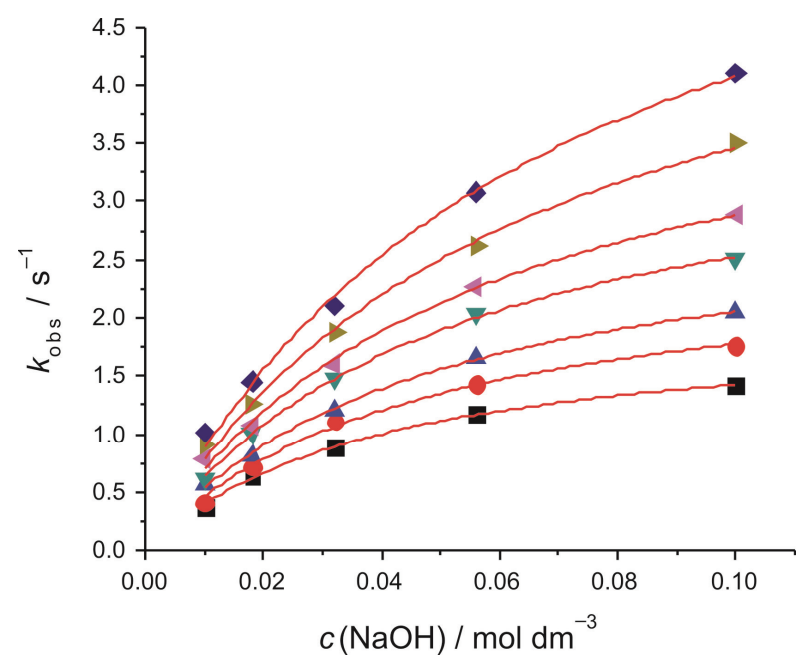

Figure 6. Dependence of the observed pseudo-first order rate constants $\left(k_{\mathrm{obs}}\right)$ on the acidity of aqueous solutions at (from bottom) $10.8,15.0,20.2,25.0,29.7,35.0$ and $40.2{ }^{\circ} \mathrm{C}$. Conditions: $c(\mathrm{MetU})=7.5 \mathrm{mmol} \mathrm{dm}^{-3}, c\left(\mathrm{~K}_{3} \mathrm{Fe}(\mathrm{CN})_{6}\right)=0.25 \mathrm{mmol}$ $\mathrm{dm}^{-3}, I=2 \mathrm{~mol} \mathrm{dm}-\left(\mathrm{NaClO}_{4}\right)$.

\section{Effect of Temperature}

Since the obtained $\mathrm{p} K_{\mathrm{a}}$ of MetU is 12.67 , slight variations in $\mathrm{pH}$ and $\mathrm{p} K_{\mathrm{a}}$ with temperature should affect the value of the observed rate constant measured as a function of temperature. Hence, the temperature effect on the kinetics of the latter reaction had to be measured simultaneously as a function of temperature and the $\mathrm{OH}^{-}$concentration (Figure 6).

$K_{\mathrm{a}}$ and $k_{2}$ were calculated from the data shown in Figure 6, taking into account that within the studied temperature range the ionic product of water increases with temperature. ${ }^{39}$ The slopes and intercepts of plots shown in Figure 7 afforded calculation of the reaction enthalpy and entropy for deprotonation of MetU as well as the activation parameters for the redox reaction as follows: $\Delta_{\mathrm{a}} H=+43(1) \mathrm{kJ} \mathrm{mol}^{-1}, \Delta_{\mathrm{a}} S=-96(4) \mathrm{J} \mathrm{K}^{-1}$ $\mathrm{mol}^{-1}, \Delta H^{\ddagger}=27(1) \mathrm{kJ} \mathrm{mol}^{-1}$, and $\Delta S^{\ddagger}=-101(4) \mathrm{J} \mathrm{K}^{-1}$ $\mathrm{mol}^{-1}$.

It is obvious that since NMHU has $\mathrm{p} K_{\mathrm{a}}=9.7$, the anionic form of NMHU is the dominant reactant in 0.01 $\mathrm{M} \mathrm{NaOH}$. Accordingly, as shown by levelling off in Figure 5 (left), a slight change of $\mathrm{pH}$ caused by the dissolved NMHU and variation in temperature does not affect the reaction rate. Therefore, the observed rate constant corresponds to $k_{2}$, and the Eyring plot shown in Figure S4 should relate directly to the kinetics of the redox reaction alone. The obtained activation parameters are: $\Delta H^{\ddagger}=16(1) \mathrm{kJ} \mathrm{mol}^{-1}$ and $\Delta S^{\ddagger}=-107(4) \mathrm{J} \mathrm{K}^{-1} \mathrm{~mol}^{-1}$.

\section{Effect of the Ionic Strength}

The observed rate constant for both hydroxyureas was found to be strongly increased upon the increase of ionic strength of the reaction medium (Figure 8), clearly pointing to a reaction between similarly charged ions. Since the experiments were carried out at a high ionic strength, the extended Bjerrum-Brønsted equation was used. However, while for MetU a nonlinear dependence was obtained, for NMHU a linear dependence of $\log k_{\mathrm{obs}}$ vs. $I^{0.5}\left(1+I^{0.5}\right)^{-1}$ was obtained, as in the case of HU. ${ }^{12}$ The effect of ionic strength on $K_{\mathrm{a}}$, and in turn on the rate constant according to Eq. (4), becomes negligible only for $\left[\mathrm{H}^{+}\right]<K_{\mathrm{a}}$, since in that case the rate expression reduces to $k_{2}$. In the case of NMHU, which has a $\mathrm{p} K_{\mathrm{a}}$ of 9.7, a $0.01 \mathrm{~mol} \mathrm{dm}^{-3}$ solution of $\mathrm{NaOH}$ buffers the reaction solution exactly in that range. Although somewhat unexpected, the obtained linearity for HU and NMHU could be justified by the annulations of certain contraeffects on the reaction rate, and considering the charge of the hydroxamate ion $(-1)$ and the calculated slopes $(+1.5)$ for the reaction of NMHU, the hexacyanoferrate charge can be speculated as -1.5 . This can be explained,
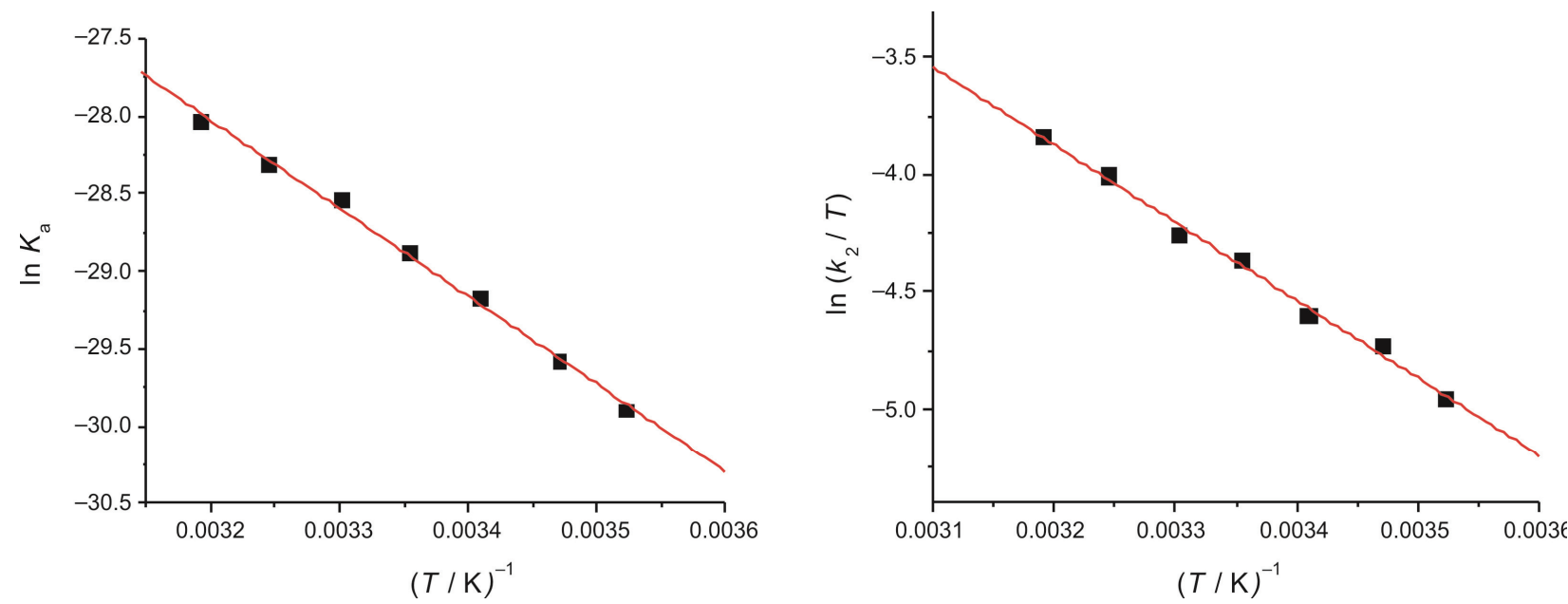

Figure 7. Dependence of the $\ln K_{\mathrm{a}}$ and $\ln \left(k_{2} / T\right)$ on the inverse temperature. Conditions: $c\left(\mathrm{~K}_{3} \mathrm{Fe}(\mathrm{CN})_{6}\right)=0.5 \mathrm{mmol} \mathrm{dm}^{-3}, c\left(\mathrm{NaOH}^{-}\right)$ $=0.01 \mathrm{M}, I=2 \mathrm{~mol} \mathrm{dm}^{-3}$. (left) $c\left(\right.$ MetU) $=7.5 \mathrm{mmol} \mathrm{dm}^{-3}$, (right) $c(\mathrm{MetU})=10 \mathrm{mmol} \mathrm{dm}^{-3}$. 

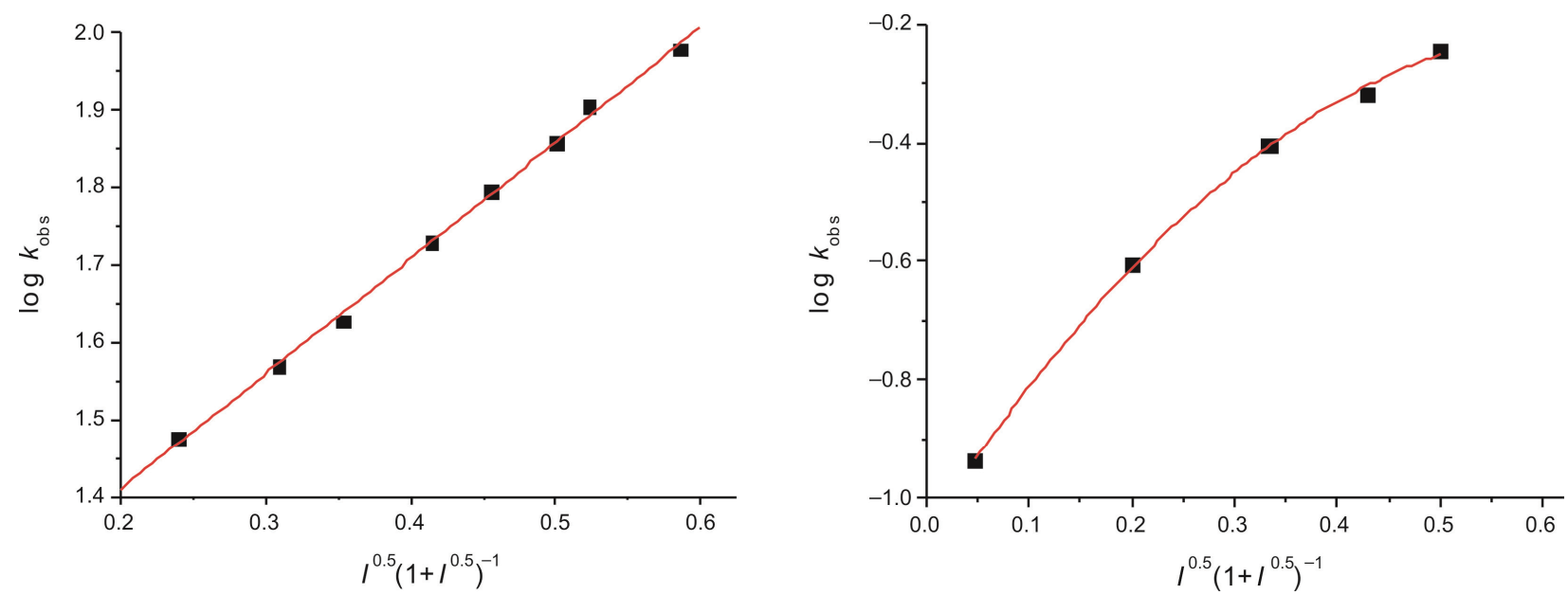

Figure 8. Dependence of the observed pseudo-first order rate constants $\left(k_{\mathrm{obs}}\right)$ on the ionic strength. (left) Conditions: $c\left(\mathrm{~K}_{3} \mathrm{Fe}(\mathrm{CN})_{6}\right)=0.5 \mathrm{mmol} \mathrm{dm}^{-3}, c(\mathrm{NMHU})=5 \mathrm{mmol} \mathrm{dm}{ }^{-3}, \mathrm{pH}=12.0, \theta=(25 \pm 0.1){ }^{\circ} \mathrm{C}$; (right) Conditions: $c\left(\mathrm{~K}_{3} \mathrm{Fe}(\mathrm{CN})_{6}\right)=0.25$ mmol dm${ }^{-3}, c(\mathrm{MetU})=7.5 \mathrm{mmol} \mathrm{dm}{ }^{-3}, \mathrm{pH}=12.0, \theta=(25 \pm 0.1)^{\circ} \mathrm{C}$. The theoretical curve of the right side figure is defined as: $\log k_{\mathrm{obs}}=-1.05+2.62 x-2.00 x^{2}$, where $x=I^{0.5}\left(1+I^{0.5}\right)^{-1}$.

as in the case of $\mathrm{HU}^{13}$ by the formation of $\left\{\mathrm{Na}^{+}{ }_{x} . \mathrm{Fe}(\mathrm{CN})_{6}{ }^{3-}\right\}$ ionic associates.

The nonlinearity observed for MetU in the plot of $\log k_{\mathrm{obs}}$ vs. $I^{0.5}\left(1+I^{0.5}\right)^{-1}$ could be caused by a simultaneous effect of ionic strength on the ionization of MetU. Such an effect cannot be eliminated by working within the $\mathrm{pH}$ range where the anionic form dominates because of a very high $\mathrm{p} K_{\mathrm{a}}$ value of MetU. According to Eq. (4), the observed rate constant is essentially a product of multiplication of the r.d.s. oxidation rate constant by a fraction of the anionic form of methoxyurea $\left(=K_{\mathrm{a}}\left(\left[\mathrm{H}^{+}\right]+\right.\right.$ $\left.K_{\mathrm{a}}\right)^{-1}$ ). Since in $0.01 \mathrm{~mol} \mathrm{dm}^{-3}$ aqueous $\mathrm{NaOH}$ the anionic form of MetU does not entirely predominate, the ionic strength could affect its fraction by changing the value of deprotonation constant. By combining the extended Debye-Hückel and Bjerrum-Brønsted equations for $k_{2}$ and $K_{\mathrm{a}}$, the observed rate constant dependence on ionic strength is rather complex and can be expressed as: $\log k_{\mathrm{obs}}=\log K_{\mathrm{a}} k_{2}=-2 Q\left(1+Z_{\mathrm{A}} Z_{\mathrm{B}}\right) I^{0.5}\left(1+I^{0.5}\right)^{-1}+$ constant. At $25^{\circ} \mathrm{C}, Q$ has a value of 0.51 , so $\log k_{\mathrm{obs}} \approx-$ $\left(1+Z_{\mathrm{A}} Z_{\mathrm{B}}\right) I^{0.5}\left(1+I^{0.5}\right)^{-1}+$ constant. Additionally, since at the high ionic strengths the Bjerrum-Brønsted equation and the Debye-Hückel limiting law fail, the only meaningful parameter easy to obtain from Figure 8 (right) is the limiting slope. Its value is 2.62 , which according to the above equation is in agreement with the hexacyanoferrate species bearing three negative charges, and a strong ion-pair formation of this ion with $\mathrm{Na}^{+}$ion even at the lowest ionic strength used in this study.

\section{Computation of the Thermodynamic Parameters for Deprotonation of MetU}

B3LYP method was used throughout this study for the first optimizations and energy calculations, and then B2PLYP and G3B3 were used on the optimized geometries.
The $\mathrm{p} K_{\mathrm{a}}$ values were calculated using equation (5),

$$
\mathrm{p} K_{\mathrm{a}}=\left(\Delta_{\mathrm{a}} G / R T \ln 10\right)-\log c_{\mathrm{H}_{2} \mathrm{O}}
$$

whereas the reaction Gibbs free energy for acid ionization in water, $\Delta_{\mathrm{a}} G_{(\mathrm{aq} .)}$, was defined by equations (6) and (7).

$$
\begin{aligned}
& \Delta_{\mathrm{a}} G_{\text {(aq.) }}=\Delta_{\mathrm{a}} G_{\text {(g) }}+\Delta_{\text {solv. }} G_{\mathrm{A}^{-} \text {(aq.) }}+\Delta_{\text {solv. }} G_{\mathrm{H}_{3} \mathrm{O}^{+} \text {(aq.) }} \\
& -\Delta_{\text {solv. }} G_{\mathrm{HA}(\text { aq.) }}-\Delta_{\text {solv. }} G_{\mathrm{H} 2 \mathrm{O}(\text { aq. })} \\
& \Delta_{\mathrm{a}} G_{(\mathrm{g})}=G_{\mathrm{A}^{-}(\mathrm{g})}+G_{\mathrm{H}_{3} \mathrm{O}^{+}(\mathrm{g})}-G_{\mathrm{HA}(\mathrm{g})}-G_{\mathrm{H}_{2} \mathrm{O}(\mathrm{g})}
\end{aligned}
$$

The respective standard Gibbs free energies of $\mathrm{H}_{2} \mathrm{O}(\mathrm{g})$ and $\mathrm{H}_{3} \mathrm{O}^{+}(\mathrm{g})$, and the energies of their solvation were calculated at the B3LYP/6-31+G(d) theory level. The calculation afforded the value of $1134.2 \mathrm{~kJ} \mathrm{~mol}^{-1}$ for the hydrated $\mathrm{H}^{+}$ion, which favourably compares to the reported value of $1129.6 \mathrm{~kJ} \mathrm{~mol}^{-1}$. 40

The gas phase Gibbs free energies calculated at the B3LYP/6-31+G(d) level reveal that the molecular and anionic forms of MetU are mixtures of trans and cis conformations. The calculated $\Delta G$ for the deprotonation at amine (NHC) site was ca. $28 \mathrm{~kJ} \mathrm{~mol}^{-1}$ larger than for the deprotonation at hydroxylamine (CNO) site. This corresponds to $c a$. 5 units larger $\mathrm{p} K_{\mathrm{a}}$ for the NHC site in the gas phase, indicating that only the deprotonation at the CNO site should be considered.

Furthermore, calculation of the hydration energy of amidic monosubstituted anions $\left(\mathrm{R}-\mathrm{NH}^{-}\right)$proved to be a very difficult task in general. For the anions of acetamide $(-920.6 \mathrm{~kJ} / \mathrm{mol})$, urea $\left(-2568.1 \mathrm{~kJ} \mathrm{~mol}^{-1}\right)$, hydroxyurea $\left(-1598.8 \mathrm{~kJ} \mathrm{~mol}^{-1}\right)$, methylamine $(-2579.3$ 
Table 1. Calculated standard Gibbs free energies, $G_{\text {tot }}$, for various forms of MetU at $298.15 \mathrm{~K}$ calculated in the gas phase and water solution at various levels of theory

\begin{tabular}{|c|c|c|c|c|c|c|}
\hline species & $\begin{array}{c}G_{\text {tot }} / \text { a.u. } \\
(\mathrm{CPCM}, 298 \mathrm{~K})\end{array}$ & $\begin{array}{l}\% \text { of cis or } \\
\text { trans form }\end{array}$ & $\begin{array}{c}\text { weighted average } \\
\mathrm{G}_{\mathrm{tot}} / \text { a.u. }\end{array}$ & $\frac{\Delta_{\mathrm{r}} G^{*}}{\mathrm{~kJ} \mathrm{~mol}^{-1}}$ & $\mathrm{p} K$ & $\begin{array}{c}\mathrm{p} K_{\mathrm{a}} \\
(=\mathrm{p} K-\log 55.6)\end{array}$ \\
\hline \multicolumn{7}{|c|}{ B3LYP/6-31+G(d) } \\
\hline cis $-\mathrm{H}_{2} \mathrm{NC}(=\mathrm{O}) \mathrm{NHOCH}_{3}$ & -339.8464782 & 5 & -32084013 & \multirow{6}{*}{81.8} & \multirow{6}{*}{14.34} & \multirow{6}{*}{12.59} \\
\hline trans $-\mathrm{H}_{2} \mathrm{NC}(=\mathrm{O}) \mathrm{NHOCH}_{3}$ & -339.8492683 & 95 & \multirow{5}{*}{-339.38597} & & & \\
\hline cis $-\mathrm{H}_{2} \mathrm{NC}(=\mathrm{O}) \mathrm{NOCH}_{3}{ }^{-}$ & -339.3861657 & 64 & & & & \\
\hline trans $-\mathrm{H}_{2} \mathrm{NC}(=\mathrm{O}) \mathrm{NOCH}_{3}^{-}$ & -339.3856213 & 36 & & & & \\
\hline $\mathrm{H}_{3} \mathrm{O}^{+}$ & -76.9120724 & & & & & \\
\hline $\mathrm{H}_{2} \mathrm{O}$ & -76.4800820 & & & & & \\
\hline \multicolumn{7}{|c|}{ G3B3 } \\
\hline cis $-\mathrm{H}_{2} \mathrm{NC}(=\mathrm{O}) \mathrm{NHOCH}_{3}$ & -339.58325409 & 13 & & \multirow{6}{*}{82.69} & \multirow{6}{*}{14.48} & \multirow{6}{*}{12.74} \\
\hline trans $-\mathrm{H}_{2} \mathrm{NC}(=\mathrm{O}) \mathrm{NHOCH}_{3}$ & -339.58508721 & 87 & \multirow{5}{*}{-339.10236} & & & \\
\hline cis $-\mathrm{H}_{2} \mathrm{NC}(=\mathrm{O}) \mathrm{NOCH}_{3}^{-}$ & -339.10261665 & 81 & & & & \\
\hline trans $-\mathrm{H}_{2} \mathrm{NC}(=\mathrm{O}) \mathrm{NOCH}_{3}^{-}$ & -339.10127746 & 19 & & & & \\
\hline $\mathrm{H}_{3} \mathrm{O}^{+}$ & -76.87160210 & & & & & \\
\hline $\mathrm{H}_{2} \mathrm{O}$ & -76.42059553 & & & & & \\
\hline \multicolumn{7}{|c|}{ B2PLYP/6-311+G(d,p) } \\
\hline cis $-\mathrm{H}_{2} \mathrm{NC}(=\mathrm{O}) \mathrm{NHOCH}_{3}$ & -339.63404423 & 10 & & \multirow{6}{*}{76.07} & \multirow{6}{*}{13.33} & \multirow{6}{*}{11.58} \\
\hline trans $-\mathrm{H}_{2} \mathrm{NC}(=\mathrm{O}) \mathrm{NHOCH}_{3}$ & -339.63611679 & 90 & \multirow{5}{*}{-339.17080} & & & \\
\hline cis $-\mathrm{H}_{2} \mathrm{NC}(=\mathrm{O}) \mathrm{NOCH}_{3}^{-}$ & -339.17104899 & 84 & & & & \\
\hline trans $-\mathrm{H}_{2} \mathrm{NC}(=\mathrm{O}) \mathrm{NOCH}_{3}{ }^{-}$ & -339.16945147 & 16 & & & & \\
\hline $\mathrm{H}_{3} \mathrm{O}^{+}$ & -76.88569932 & & & & & \\
\hline $\mathrm{H}_{2} \mathrm{O}$ & -76.44956552 & & & & & \\
\hline
\end{tabular}

(a) The reaction free energy (given in $\mathrm{kJ} \mathrm{mol}^{-1}$ ) corresponding to: $\mathrm{HA}+\mathrm{H}_{2} \mathrm{O} \rightleftarrows \mathrm{A}^{-}+\mathrm{H}_{3} \mathrm{O}^{+}$

$\mathrm{kJ} \mathrm{mol}^{-1}$ ) and ammonia $\left(-1144.1 \mathrm{~kJ} \mathrm{~mol}^{-1}\right)$ calculations afforded similar, unexpectedly large hydration energies. These values are much larger than the ones calculated for amidic disubstituted anions $\left(\mathrm{R}_{1} \mathrm{R}_{2} \mathrm{~N}^{-}\right)$species, where nitrogen is bonded to two fragments, as in anions of $N$-methylacetamide $\left(-284.6 \quad \mathrm{~kJ} \quad \mathrm{~mol}^{-1}\right), \quad N$-methylhydroxyurea $\left(-288.6 \mathrm{~kJ} \mathrm{~mol}^{-1}\right), N$-methylmetoxyurea $\left(-311.5 \mathrm{~kJ} \mathrm{~mol}^{-1}\right)$, and $N_{1}, N_{3}$-dimethyl-urea $(299.2 \mathrm{~kJ}$ $\mathrm{mol}^{-1}$ ) (Table S1). The calculated free energy of hydration for the MetU anion deprotonated at the NHC site was calculated to be at least $140 \mathrm{~kJ} \mathrm{~mol}^{-1}$ larger than for the anion deprotonated at the $\mathrm{CNO}$ site. Therefore, only the $\mathrm{CNO}$ deprotonation site was considered further in this paper.

Hydration of different conformations of neutral and anionic forms of MetU was done treating the water both implicitly as included in CPCM methods and as a discrete solvent molecule combined with CPCM methods. On B3LYP/6-31+G(d) level of theory (Table 1), when the Boltzmann distribution was taken into account, $\mathrm{p} K_{\mathrm{a}}$ was calculated as 12.54 , which is in excellent agreement with the experimentally obtained value. Us- ing a model with one discrete water molecule added, the calculated value of $\mathrm{p} K_{\mathrm{a}}$ was 14.84 (Table S2). The lowest minima computed at B3LYP/6-31+G(d) level were then used as a starting structures for G3B3 and B2PLYP calculations. G3B3 afforded a value $\mathrm{p} K_{\mathrm{a}}=12.73$ for implicitly included effect of water, but much smaller $\mathrm{p} K_{\mathrm{a}}=10.00$ for explicitly added one water molecule. B2PLYP afforded $\mathrm{p} K_{\mathrm{a}}=11.55$ for implicitly included effect of water and $\mathrm{p} K_{\mathrm{a}}=15.16$ for explicitly added one water molecule.

Comparing all three methods we can safely assume that the implicit model, without the addition of a discrete water molecule, is a satisfactory model for the calculations on MetU with Gaussian09. B3LYP and G3B3 gave similar results, while B2PLYP underestimated $\mathrm{p} K_{\mathrm{a}}$ when no water molecule was explicitly added and overestimated when one discrete water molecule was added. The difference between the $\mathrm{p} K_{\mathrm{a}}$ values estimated from the implicit model and the model with one water molecule explicitly added can be attributed to the over/underestimation of entropy effects by Gaussian program. ${ }^{41}$ Therefore, the computations reveal that the 
Table 2. Equilibrium and kinetic parameters for deprotonation and oxidation of hydroxyureas with $\mathrm{Fe}(\mathrm{CN})_{6}{ }^{3-}$, at $25^{\circ} \mathrm{C}$ and $2 \mathrm{M}$ ionic strength $\left(\mathrm{NaClO}_{4}\right)$

\begin{tabular}{|c|c|c|c|c|c|c|c|}
\hline $\begin{array}{l}\text { Parameter } \Rightarrow \\
\text { Compound } \Downarrow\end{array}$ & $\mathrm{p} K_{\mathrm{a}}\left(25^{\circ} \mathrm{C}\right)$ & $\frac{\Delta_{\mathrm{a}} H}{\mathrm{~kJ} \mathrm{~mol}^{-1}}$ & $\frac{\Delta_{\mathrm{a}} S}{\mathrm{~J} \mathrm{~K}^{-1} \mathrm{~mol}^{-1}}$ & $\frac{k_{1}\left(25^{\circ} \mathrm{C}\right)}{\mathrm{mol}^{-1} \mathrm{dm}^{3} \mathrm{~s}^{-1}}$ & $\frac{k_{2}\left(25^{\circ} \mathrm{C}\right)}{\mathrm{mol}^{-1} \mathrm{dm}^{3} \mathrm{~s}^{-1}}$ & $\frac{\Delta_{2} H^{\ddagger}}{\mathrm{kJ} \mathrm{mol}^{-1}}$ & $\frac{\Delta_{2} S^{\ddagger}}{\mathrm{J} \mathrm{K}^{-1} \mathrm{~mol}^{-1}}$ \\
\hline MetU & $12.7 \pm 0.1$ & $43 \pm 1$ & $-96 \pm 4$ & - & $(5.06 \pm 0.01) \times 10^{2}$ & $27 \pm 1$ & $-101 \pm 4$ \\
\hline $\mathrm{HU}$ & $\begin{array}{l}10.69^{(\mathrm{a})} \\
10.15^{(\mathrm{b})}\end{array}$ & $\begin{array}{c}37.8^{(\mathrm{a})} \\
7.6^{(\mathrm{b})}\end{array}$ & $\begin{array}{l}-81^{(\mathrm{a})} \\
-169^{(\mathrm{b})}\end{array}$ & $<0.15$ & $3.6 \times 10^{3}$ & 27 & -76 \\
\hline NMHU & $\begin{array}{c}9.82 \pm 0.02 \\
9.79^{(b)}\end{array}$ & $4.9^{(\mathrm{b})}$ & $-171^{(\mathrm{b})}$ & $(1 \pm 1) \times 10^{2}$ & $(1.92 \pm 0.02) \times 10^{4}$ & $16 \pm 1$ & $-107 \pm 4$ \\
\hline
\end{tabular}

(a) Data from Ref. 12, parameters determined kinetically.

(b) Data from Ref. 18, parameters determined potentiometrically.

deprotonation site of MetU in aqueous solution is the hydroxylamino nitrogen rather than the amide nitrogen atom. Geometries of the most stable minima are given in supplementary information (Table S4).

\section{DISCUSSION}

In this study we investigated the mechanism of oxidation of the hydroxyurea derivatives with hexacyanoferrate(III) in aqueous solutions. As already shown for HU, for both derivatives of hydroxyurea that were studied, the dependence of the rate of oxidation on the acidity of aqueous solutions shows that the anions are much more reactive than the molecular forms. The stoichiometric ratio $\left[\mathrm{Fe}(\mathrm{CN})_{6}{ }^{3-}\right] /[\mathrm{NMHU}]$ in the redox reaction between $\mathrm{Fe}(\mathrm{CN})_{6}{ }^{3-}$ and $\mathrm{NMHU}$ was found to be 2, the same as found for the reactions of HU with dioxovana$\operatorname{dium}(\mathrm{V})$ and $\mathrm{Fe}(\mathrm{CN})_{6}{ }^{3-}$ ions, while the stoichiometric ratio $\left[\mathrm{Fe}(\mathrm{CN})_{6}{ }^{3-}\right] /[\mathrm{MetU}]$ in the redox reaction between $\mathrm{Fe}(\mathrm{CN})_{6}{ }^{3-}$ and $\mathrm{MetU}$ was found to be 1 . These results indicate that neither $\mathrm{VO}_{2}{ }^{+}$nor $\mathrm{Fe}(\mathrm{CN})_{6}{ }^{3-}$ ions can oxidize HU, NMHU, or MetU to NO because the conversion of the hydroxyureas to NO is a three-electron oxidation process. The obtained difference in stoichiometric coefficients of the hydroxyurea derivatives indicates a rather different reaction mechanism operative in oxidation of MetU compared to the oxidation of NMHU and HU.

The results reveal that free radicals are formed as the reactive intermediates during the oxidation of all three hydroxyureas. The obtained spectral parameters of EPR measurements reveal that the same free radical is formed in the oxidation of NMHU with both $\mathrm{Fe}(\mathrm{CN})_{6}{ }^{3-}$ and dioxovanadium $(\mathrm{V})$ ions, as already reported for the oxidation of HU with these two oxidants. Our failure to detect the free radical derived from MetU by EPR spectroscopy indicates that this free radical is present at much lower concentration than the free radicals generated either from $\mathrm{HU}$ or NMHU. This could be a consequence of a much lower stability of the former one, or, more probably, its much slower formation.
Based on the above arguments the following reaction mechanism is proposed (Scheme 1).

$$
\begin{aligned}
& \mathrm{HA}+\mathrm{OH}^{-} \rightleftharpoons \mathrm{A}^{-}+\mathrm{H}_{2} \mathrm{O} \\
& \left(\mathrm{HA}=\mathrm{H}_{2} \mathrm{~N}-\mathrm{CO}-\mathrm{NR}^{1}-\mathrm{OR}^{2}\right)
\end{aligned}
$$

$$
\begin{aligned}
& \mathrm{HA}+\mathrm{Fe}(\mathrm{CN})_{6}{ }^{3-} \underset{\mathrm{rds}}{\stackrel{k_{1}}{\longrightarrow}} \mathrm{A}^{\cdot}+\mathrm{Fe}(\mathrm{CN})_{6}{ }^{4-}+\mathrm{H}^{+} \\
& \mathrm{A}^{-}+\mathrm{Fe}(\mathrm{CN})_{6}{ }^{3-} \underset{\text { rds }}{\stackrel{k_{2}}{\longrightarrow}} \mathrm{A}^{\cdot}+\mathrm{Fe}(\mathrm{CN})_{6}{ }^{4-}
\end{aligned}
$$

$$
\begin{aligned}
& \mathrm{A}^{\cdot}+\mathrm{H}_{2} \mathrm{O} \longrightarrow \mathbf{X} \\
& \mathbf{X}+\mathrm{A}^{\cdot} \longrightarrow \text { products }
\end{aligned}
$$

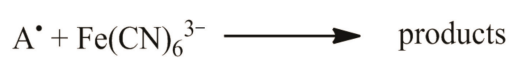

Scheme 1.

The first step represents a fast deprotonation preequilibrium, followed by the rate determining step (ii). Step (iii) allows for the obtained stoichiometric coefficients in the oxidation of MetU, probably representing the termination step. On the other hand, step (iv) is necessary for NMHU and HU, since these two compounds act as two-electron donors in the studied redox reactions. Table 2 lists all the calculated deprotonation, thermodynamic, kinetic and activation parameters.

The data in Table 2 reveal that $(i)$ the second order rate constants of the redox reactions are inversely related to the basicities of the hydroxyureates, $(i i)$ the rate constant of redox reaction decreases or increases upon the substitution of methyl group for $\mathrm{H}$ atom at the hydroxamate oxygen (MetU) or nitrogen (NMHU) atom of 
HU, respectively, and (iii) the substitution at the hydroxamate oxygen is only a slightly more effective than the substitution at the nitrogen atom.

Since the charges of all three hydroxyureates are equal $(-1)$, the ion-pair association constants between the $\mathrm{Fe}(\mathrm{CN})_{6}{ }^{3-}$ and the anions mediated by $\mathrm{Na}^{+}$ion(s) are expected also to be nearly equal. Hence, one may reasonably assume that the primary reason for the observed decrease of rate constant upon the substitution of methyl group for $\mathrm{H}$ atom is the bulkiness of the methyl substituent in MetU, but such an explanation does not comprehend the observed accelerating effect of the substitution in NMHU. The EPR spectroscopic characterizations of the HU and NMHU free radicals, showing that the spin density is localized at the hydroxamate oxygen atom, may help reconcile these apparently contradictory results. It could be speculated that in order for the successful reactive contact to occur, $\mathrm{Fe}(\mathrm{CN})_{6}{ }^{3-}$ should approach the hydroxamate oxygen atom. If the same is true for the free radical of MetU, which cannot be structurally characterized because it was detected only by the acrylamide polymerization test but not by EPR spectroscopy, then the electron donor site in MetU could also be the oxygen atom and not the nitrogen atom where the deprotonation occurs.

However, before any further discussion of this hypothesis, the deprotonation site of MetU has to be ascertained as much as possible. A large number of papers dealing with theoretical and experimental aspects of hydroxamic acids' acidities has been published ${ }^{14,15,19,42-54}$ in order to determine whether these compounds are nitrogen or oxygen acids. The electronic properties of the functional groups attached to the hydroxamate moiety were found to play a dominant role in the ionization of hydroxamic acids. A plot of the reaction enthalpies vs. entropies for a series of small monohydroxamic acids shown in Figure 9 clearly illustrates that the thermodynamic parameters determined for ionization of hydroxyureas, and particularly for MetU, exhibit a significant deviation from the theoretical straight line defined by Crumbliss and coworkers. Since the hydroxamic acids used by Crumbliss and collaborators were apparently O-acids, the deviation from theoretical line could be explained by invoking the deprotonation at the N-site. The observed deviation for HU was explained by the participation of the N-site in the deprotonation. ${ }^{55}$ An effort was made to explain a smaller but evident deviation observed for NMHU by unexpectedly negative reaction entropy for deprotonation at the $\mathrm{O}$ site, but the hypothesis was not confirmed by the performed calculations.

Nevertheless, it is clear that the MetU data-point deviates from the Crumbliss straight line by far more than the data-points of other two hydroxyureas, indicating clearly that the deprotonation of MetU does not

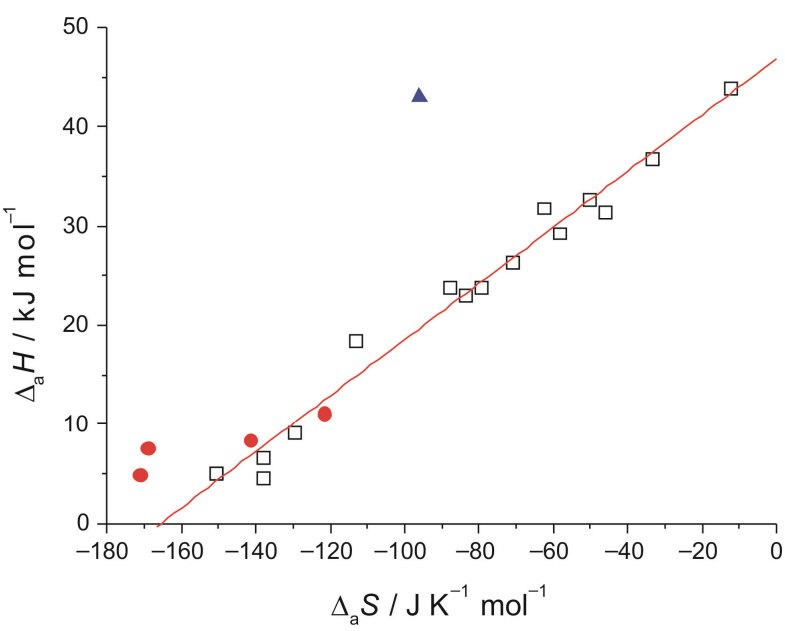

Figure 9. Plot of $\Delta_{\mathrm{a}} H$ vs. $\Delta_{\mathrm{a}} S$ for investigated hydroxamic acids at $I=2 \mathrm{~mol} \mathrm{dm}^{-3}$ : squares; data from Refs. 17, 56, 57 and 58, circles; data from Ref. 18 and triangle; data point for MetU, this work.

follow the same reaction pattern proposed for other monohydroxamic acids in the series. Making the deprotonation of MetU possible only at the N-site (by the substitution of the methyl group for the hydrogen atom), the observed deviation from the straight line additionally corroborates the suggestion that the distinction between the deprotonation sites of low molecular weight hydroxamic acids in water is possible on the basis of the linear relationship between the reaction enthalpy and entropy.

Unlike NMHU, where the substitution of the methyl group for the hydrogen atom at the hydroxamato nitrogen atom causes the deprotonation to occur exclusively at the oxygen atom, and HU, where the deprotonation occurs at both sites, in MetU the deprotonation is forced to occur only at the less electronegative atom, i.e. at one of the nitrogen atoms. The results of $a b$ initio computations point to the hydroxamate nitrogen atom as the single deprotonation site in MetU.

The reduction of electron density at the redox reactive site in methoxyureate compared to $\mathrm{N}$ methylhydroxyureate, caused by dislocation of the electron-transfer from the deprotonation sites, should retard the rate determining electron transfer to hexacyanoferrate(III) ion. A slight increase of the electron density on the hydroxamate oxygen atom of MetU, caused by the substitution of the methyl group for the hydrogen atom, obviously cannot compensate for that effect.

Therefore, the inverse correlation of rate constants of the electron transfer from the hydroxyureates to $\mathrm{Fe}(\mathrm{CN})_{6}{ }^{3-}$ with basicities of hydroxyureates, could be speculated to occur mainly because the deprotonation and the electron donating sites do not overlap each others. In other words, whereas the electronic properties of 

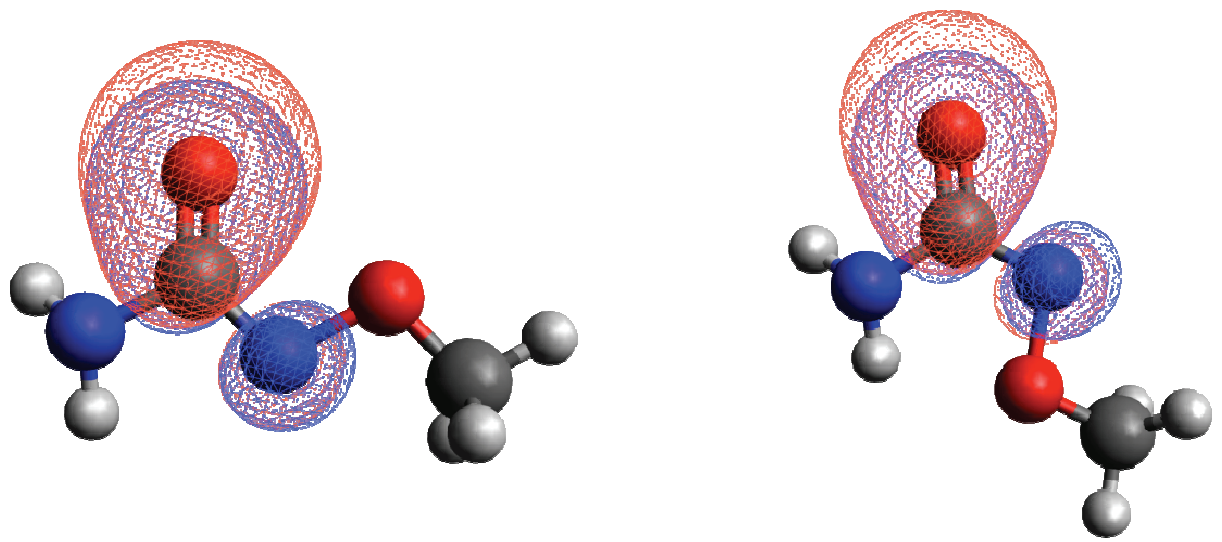

Figure 10. $\mathrm{HOMO}$ orbitals of cis- and trans $-\mathrm{H}_{2} \mathrm{NC}(=\mathrm{O}) \mathrm{NOCH}_{3}{ }^{-}$obtained by $\mathrm{NBO}$ analysis.

the hydroxamate nitrogen atom play a crucial role in the ionization of the methoxyurea molecule, a crucial role in the kinetics of electron transfer is played by the electronic properties of the oxygen atom in methoxyureate.

In order to test this hypothesis, ab initio theoretical calculations were carefully analyzed for the three hydroxyureates studied. As expected, the performed calculations strongly indicated that the deprotonation site in MetU is indeed the hydroxamate nitrogen atom alone, because $\mathrm{p} K_{\mathrm{a}}$ of the amine group in methoxyurea was estimated to be almost five units higher. The calculated distribution of the negative charge in methoxyureate, based on the performed NBO analysis (Table S3), indicated almost equal charges $(-0.48)$ on the hydroxamate nitrogen and oxygen atoms, and a much larger negative charge on the carbonyl oxygen $(-0.79)$. The calculated HOMO of methoxyureate, from which the electron transfer to hexacyanoferrate(III) is expected to occur, is composed mostly of the carbonyl-oxygen $p$ atomic orbital $(>80 \%)$, while the participation of the hydroxamate nitrogen $p$ AO (ca. $5 \%)$ in HOMO is negligible (Figure 10). As expected, a negligible par- ticipation of the amine-nitrogen $\mathrm{AO}$ in the anion's HOMO was predicted by NBO analysis, but an unexpectedly weak participation of the hydroxyl-oxygen $\mathrm{AO}$ was also found.

NBO analysis performed on $N$-methylhydroxyureate (NMHU can deprotonate only the $-\mathrm{OH}$ site) showed that HOMO is located only on the hydroxyl oxygen atom of each anion, cis- or trans- $\mathrm{H}_{2} \mathrm{NC}(=\mathrm{O}) \mathrm{NCH}_{3} \mathrm{O}^{-}$ (Figure 11). The charges on the hydroxamate oxygen atom $(-0.75)$ and the carbonyl oxygen atom $(-0.74)$ are almost the same, but the charge on the hydroxamate nitrogen atom is much smaller $(-0.20)$.

A similar analysis carried out on HU reveals that when deprotonation occurs at the hydroxamate nitrogen, $\mathrm{H}_{2} \mathrm{NC}(=\mathrm{O}) \mathrm{NOH}^{-}$is produced and the HOMO is located on the carbonyl oxygen atom of anion (Figure 12 top). The charge distribution is similar to that in MetU, i.e. similar charges on hydroxamate oxygen $(-0.64)$ and nitrogen $(-0.54)$ atoms, and a larger negative charge on the carbonyl oxygen $(-0.82)$. When the deprotonation of $\mathrm{HU}$ occurs at the $-\mathrm{OH}$ site, $\mathrm{H}_{2} \mathrm{NC}(=\mathrm{O}) \mathrm{NHO}^{-}$is produced and the anion's HOMO is located on the hydroxyl
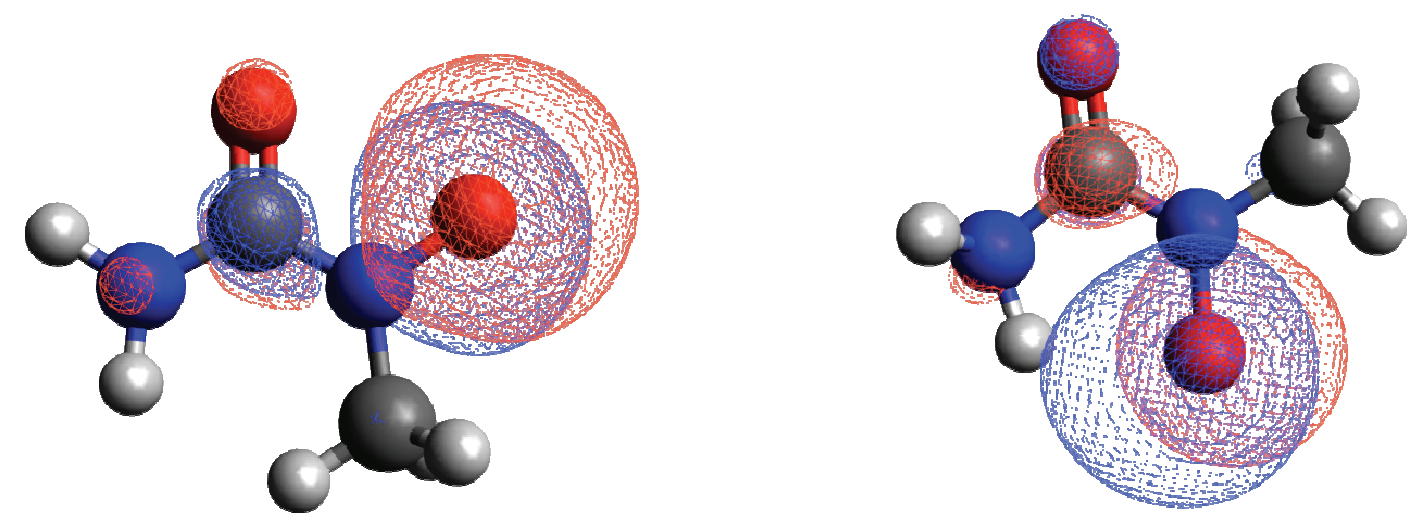

Figure 11. $\mathrm{HOMO}$ orbitals of cis- and trans $-\mathrm{H}_{2} \mathrm{NC}(=\mathrm{O}) \mathrm{NCH}_{3} \mathrm{O}^{-}$obtained by $\mathrm{NBO}$ analysis. 

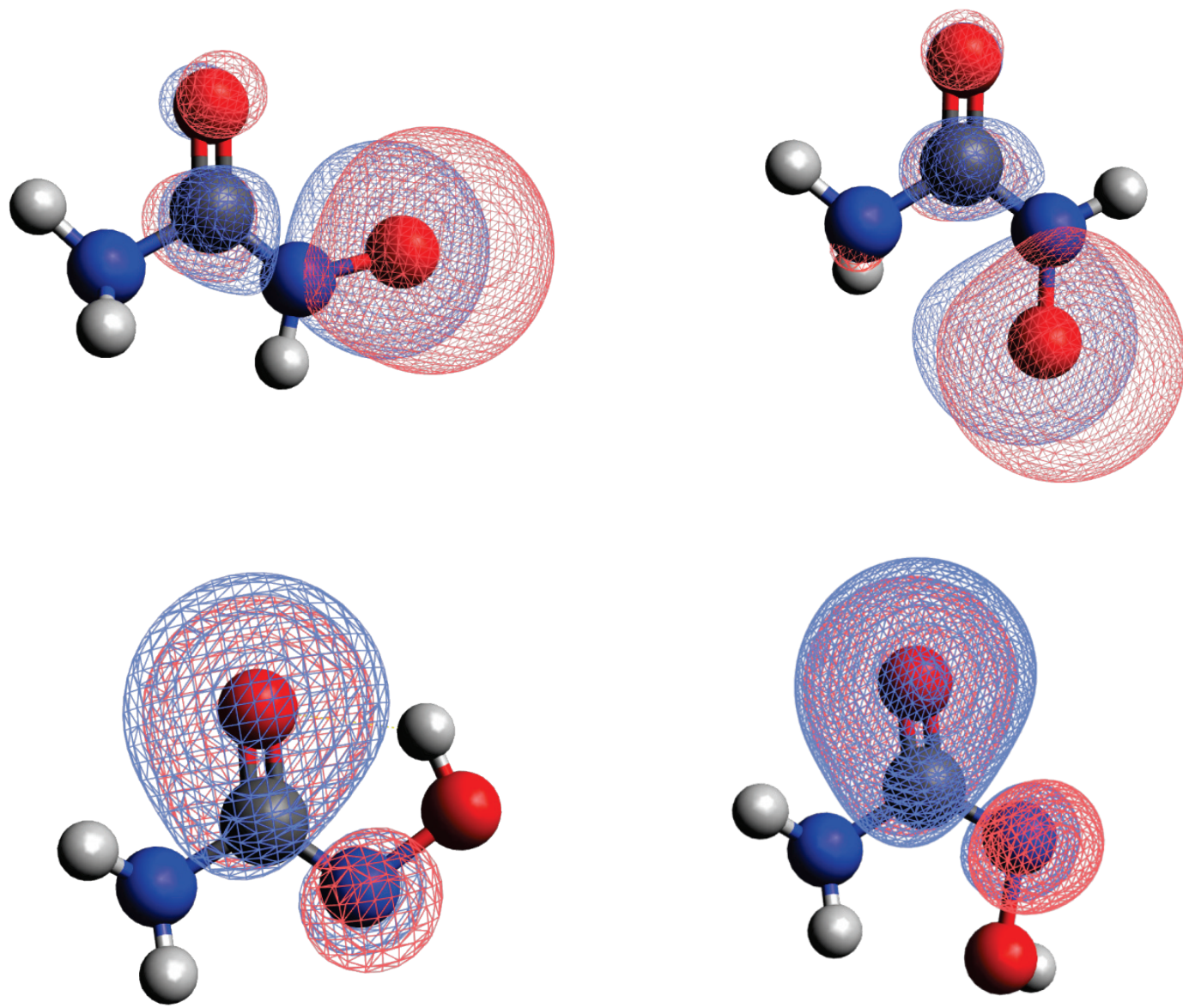

Figure 12. $\mathrm{HOMO}$ orbitals of (top) cis- and trans $-\mathrm{H}_{2} \mathrm{NC}(=\mathrm{O}) \mathrm{NHO}^{-}$and (bottom) cis- and trans $\left.-\mathrm{H}_{2} \mathrm{NC}=\mathrm{O}\right) \mathrm{NOH}^{-}$obtained by NBO analysis.

oxygen atom (Figure 12 bottom). The difference in charge between the hydroxamate oxygen $(-0.76)$ and nitrogen $(-0.32)$ atoms was computed, but an even larger negative charge was found on the carbonyl oxygen atom $(-0.82)$.

We can conclude that depending on whether the particular hydroxyurea derivative is behaving as an $\mathrm{N}$-acid or an $\mathrm{O}$-acid, HOMO orbitals are predominately located either on the carbonyl or the hydroxamate oxygen atom, respectively, but never on the nitrogen atom. Any of these HOMO orbitals can favourably overlap an empty antibonding $\mathrm{C}-\mathrm{N}$ orbital of the coordinated cy anide ligand in $\mathrm{Fe}(\mathrm{CN})_{6}{ }^{3-}$ ion, making the electron transfer feasible. Thus, the performed NBO analysis provides a plausible explanation for the observed inverse dependence of the r.d.s. electron transfer from the studied anions to the $\mathrm{Fe}(\mathrm{CN})_{6}{ }^{3-}$ ion on the basicities of the hydroxyureates.

Supplementary Materials. - Supporting informations to the paper are enclosed to the electronic version of the article. These data can be found on the website of Croatica Chemica Acta (http://public.carnet.hr/ccacaa).
Acknowledgements. The authors gratefully acknowledge financial support from the Croatian Ministry of Science.

\section{REFERENCES}

1. S. Nyholm, L. Thelander, and A. Graeslund, Biochemistry 32 (1993) 11569-11574.

2. B. Zhou, S. Mi, X. Mo, J. Shih, J. Tsai, E. Hu, M. Hsu, K. Kay, and Y. Yen, Anticancer Res. 22 (2002) 1369-1377.

3. S. Charache, M. L. Terrin, R. D. Moore, G. J. Dover, F. B. Barton, S. V. Eckert, R. P. McMahon, and D. R. Bonds, New Engl. J. Med. 332 (1995) 1317-1322.

4. R. P. Ferguson, A. Arun, C. Carter, S. D. Walker, and O. Castro, Am. J. Hematolo. 70 (2002) 326-330.

5. C. J. Marmion, T. Murphy, K. B. Nolan, and J. R. Docherty, Chem. Commun. 2000 1153-1154.

6. J. W. Rupon, S. R. Domingo, S. V. Smith, B. K. Gummadi, H. Shields, S. K. Ballas, S. B. King, and D. B. Kim-Shapiro, Biophys. Chem. 84 (2000) 1-11.

7. J. Huang, S. B. Hadimani, J. W. Rupon, S. K. Ballas, D. B. KimShapiro, and S. B. King, Biochemistry 41 (2002) 2466-2474.

8. J. Huang, Z. Zou, D. B. Kim-Shapiro, S. K. Ballas, and S. Bruce King, J. Med. Chem. 46 (2003) 3748-3753.

9. W. Charnulitrat, R. P. Mason, and D. Riendeaul, J. Biol. Chem. 267 (1992) 9574-9579. 
10. R. Bundy, N. Marczin, A. H. Chester, and M. Yacoub, Am. J. Physiol.-Heart Circ. Physiol. 277 (1999) 1799-1807.

11. M. Gabričević, E. Bešić, M Biruš, A. Zahl, and R. van Eldik, $J$. Inorg. Biochem. 100 (2006) 1606-1613.

12. A. Budimir, E. Bešić, and M. Biruš, Croat. Chem. Acta $\mathbf{8 2}$ (2009) 807-818.

13. Hexacyanoferrate(III) is chosen as an electron acceptor for its capability of abstracting one electron from an electron-rich site in an organic molecule by an outer-sphere electron transfer from the substrate to the metal ion, and is capable of oxidizing under both acidic and alkaline conditions and has been utilized extensively in the oxidation of organic compounds.

14. M. L. Senent, A. Niño, C. Munoz Caro, S. Ibeas, B. Garcia, J. M. Leal, F. Secco, and M. Ventirini, J. Org. Chem. 68 (2003) $6535-6542$.

15. R. Kakkar, R. Grover, and P. Chadha, Org. Biomol. Chem. 1 (2003) 2200-2206.

16. (a) R. D. Christen, D. R. Shalinski, and S. B. Howell, Proc. Am Soc. Clin. Oncol. 9 (1990) 210; (b) J. W. Berkenkopf and B. M Weichman, Eur. J. Pharmacol. 193 (1991) 29.

17. (a) L. L. Fish and A. L. Crumbliss, Inorg. Chem. 24 (1985) 2198-2294; (b) M. Biruš, S. Inić, N. Kujundžić, and B. Nigović, Croat. Chem. Acta 71 (1998) 807-816; (c) E. Farkas, E. Kozma, M. Pethö, K. M. Herlihy, and G. Micera, Polyhedron 17 (1998) 3331-3342; (d) E. Farkas, E. A. Enyedy, and H. Csóka, Polyhedron 18 (1999) 2391-2398; (e) E. Farkas, E. A. Enyedy, and H. Csóka, J. Inorg. Biochem. 79 (2000) 205-211; (f) B. Nigović, N Kujundžić, K. Sanković, and D. Vikić-Topić, Acta Chim. Slov. 49 (2002) 525-535; (g) M. Jadrijević-Mladar Takač, I. Kos, M. Biruš, I. Butula, and M. Gabričević, Journal of Molecular Structure 734 (2004) 143-150; (h) J. I. Wirgau, I. Spasojević, H. Boukhalfa, I. Batinić-Haberle, and A. L. Crumbliss, Inorg. Chem. 41 (2002) 1464-1473.

18. I. Vinković Vrček, I. Kos, T. Weitner, and M. Biruš, J. Phys. Chem. A 112 (2008) 11756-11768.

19. B. Monzyk and A. L. Crumbliss, J. Org. Chem. 45 (1980) $4670-4675$

20. W. Traube, H. Ohlendorf, and H. Zander, Berichte 53 (1920) $1477-1492$

21. Gaussian 09, Revision A.02, M. J. Frisch, G. W. Trucks, H. B. Schlegel, G. E. Scuseria, M. A. Robb, J. R. Cheeseman, G. Scalmani, V. Barone, B. Mennucci, G. A. Petersson, H. Nakatsuji, M. Caricato, X. Li, H. P. Hratchian, A. F. Izmaylov, J. Bloino, G. Zheng, J. L. Sonnenberg, M. Hada, M. Ehara, K. Toyota, R. Fukuda, J. Hasegawa, M. Ishida, T. Nakajima, Y. Honda, O. Kitao, H. Nakai, T. Vreven, J. A. Montgomery, Jr., J. E. Peralta, F. Ogliaro, M. Bearpark, J. J. Heyd, E. Brothers, K. N. Kudin, V. N. Staroverov, R. Kobayashi, J. Normand, K. Raghavachari, A. Rendell, J. C. Burant, S. S. Iyengar, J. Tomasi, M. Cossi, N. Rega, J. M. Millam, M. Klene, J. E. Knox, J. B. Cross, V. Bakken, C. Adamo, J. Jaramillo, R. Gomperts, R. E. Stratmann, O. Yazyev, A. J. Austin, R. Cammi, C. Pomelli, J. W. Ochterski, R. L. Martin, K. Morokuma, V. G. Zakrzewski, G. A. Voth, P. Salvador, J. J. Dannenberg, S. Dapprich, A. D. Daniels, O. Farkas, J. B. Foresman, J. V. Ortiz, J. Cioslowski, and D. J. Fox, Gaussian, Inc., Wallingford CT, 2009.

22. Avogadro: an open-source molecular builder and visualization tool. Version 1.01. http://avogadro.openmolecules.net/

23. M. Saunders, J. Comp. Chem. 22 (2004) 621-626.

24. M. A. Addicoat and G.F. Metha, J. Comp. Chem. 30 (2009) $57-64$.

25. A. D. Becke, $J$. Chem. Phys. 98 (1993) 5648-5652.

26. M. M. Francl, W. J. Petro, W. J. Hehre, J. S. Binkley, M. S. Gordon, D. J. DeFrees, and J. A. Pople, J. Chem. Phys. 77 (1982) 3654-3665.

27. M. Cossi, G. Scalmani, N. Rega, and V. Barone, J. Chem. Phys. 117 (2002) 43-45.
28. V. Barone, M. Cossi, B. Mennucci, and J. Tomasi, J. Chem. Phys. 107 (1997) 3210-3221.

29. S. Grimme, J. Chem. Phys. 124 (2006) 34108-34124.

30. (a) M. Head-Gordon, J. A. Pople, and M. J. Frisch, Chem. Phys. Lett. 153 (1988) 503-506; (b) S. Saebø and J. Almlöf, Chem. Phys. Lett. 154 (1989) 83-89; (c) M. J. Frisch, M. Head-Gordon, and J. A. Pople, Chem. Phys. Lett. 166 (1990) 275-280; (d) M. J. Frisch, M. Head-Gordon, and J. A. Pople, Chem. Phys. Lett. 166 (1990) 281-289; (e) M. Head -Gordon and T. Head-Gordon, Chem. Phys. Lett. 220 (1994) 122-128.

31. A. G. Baboul, L. A. Curtiss, P. C. Redfern, and K. Raghavachari, J. Chem. Phys. 110 (1999) 7650-7657.

32. (a) J. P. Foster and F. Weinhold, J. Am. Chem. Soc. 102 (1980) 7211-7218; (b) A. E. Reed and F. Weinhold, J. Chem. Phys. 78 (1983) 4066-4073; (c) J. E. Carpenter and F. Weinhold, J. Mol. Struct. (Theochem) 46 (1988) 41-62; (d) F. Weinhold and J. E. Carpenter, in The Structure of Small Molecules and Ions, R. Naaman and Z. Vager (Ed.), Plenum, New York (1988) 227-236.

33. J. M. Leal, B. Garcia, and P. L. Domingo, Coord. Chem. Rev. 173 (1998) 79-131.

34. T. Weitner, E. Bešić, I. Kos, M. Gabričević, and M. Biruš, Tetrahedron Letters $\mathbf{4 8}$ (2007) 9021-9024.

35. It should be noted that at $\mathrm{pH}<6$ for NMHU and $\mathrm{pH}<10$ for $\mathrm{MetU}$, biphasic kinetics were observed, which can be explained by coupling of the oxidation steps to the deprotonation of hydroxyureas at the higher acidity used. That work is in the progress and the results will be published elsewhere.

36. Hereafter, the figures in parentheses are the single standard deviations expressed in terms of the last significant digit reported for the parameters.

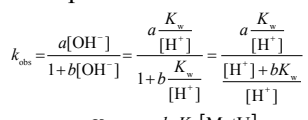

37.

$$
=\frac{a K_{\mathrm{w}}}{\left[\mathrm{H}^{+}\right]+b K_{\mathrm{w}}}=\frac{k_{2} K_{\mathrm{a}}[\mathrm{MetU}]_{\mathrm{tot}}}{\left[\mathrm{H}^{+}\right]+K_{\mathrm{a}}}
$$

$$
k_{2}=a K_{\mathrm{w}} /\left(K_{\mathrm{a}}[\mathrm{MetU}]_{\mathrm{tot}}\right)=a /\left(b[\mathrm{MetU}]_{\mathrm{otot}}\right)
$$

38. The data refer to $2 \mathrm{~mol} \mathrm{dm}^{-3}$ ionic stregth maintained by $\mathrm{NaCl}$.

39. The following values of the water ionic product $\left(\mathrm{p} K_{\mathrm{w}}(T)\right)$, taken from S. Glasstone, An Introduction to Electrochemistry, Van Nostrand East-West Press, Madras (1960) 345, were used throughout the calculations: $14.45\left(10.8^{\circ} \mathrm{C}\right), 14.31\left(15.0^{\circ} \mathrm{C}\right), 14.14(20.0$ $\left.{ }^{\circ} \mathrm{C}\right), 13.97\left(25.0{ }^{\circ} \mathrm{C}\right), 13.81\left(30.0{ }^{\circ} \mathrm{C}\right), 13.65\left(35.0^{\circ} \mathrm{C}\right)$ and 13.5 $\left(40.0^{\circ} \mathrm{C}\right)$.

40. P. Sinha, S. E. Boesch, C. Gu, R. A. Wheeler, and A. K. Wilson, J. Phys. Chem. A 108 (2004) 9213-9217.

41. (a) I. A. Topol, G. J. Tawa, S. K. Burt, and A. A. Rashin, $J$ Phys. Chem. A 101 (1997) 10075-10081; (b) M. D. Tissandier, K. A. Cowen, W. Y. Feng, E. Gundlach, M. H. Cohen, A. D. Earhart, J. V. Coe, and T. R. Tuttle, Jr., J. Phys. Chem. A 102 (1998) 7787-7794.

42. A. Bagno, C. Comuzzi, and G. Scorrano, J. Am. Chem. Soc. 116 (1994) 916-924

43. I. K. Larsen, Acta Crystallogr. Sect. B 44 (1988) 527-533.

44. D. A. Brown, R. A. Coogan, N. J. Fitzpatrick, W. K. Glass, D. E. Abuksima, L. Shields, M. Ahlgrén, K. Smolander, T. T. Pakkanen, T. A. Pakkanen, and M. Peräkkylä, J. Chem. Soc Perkin Trans. 2 (1996) 2673-2679.

45. G. La Manna and L. Barone, Intern. J. Quantum Chem. 57 (1996) 971-974

46. A. Bagno and C. Comuzzi, Eur. J. Org. Chem. 1 (1999) $287-295$.

47. M. Remko, P. D. Lyne, and W. G. Richards, Phys. Chem. Chem. Phys. 2 (2000) 2511-2514

48. M. Remko and C.-W. von Lieth, Struct. Chem. 15 (2004) 285-294.

49. G. Di Gregorio, G. La Mamna, J.C. Paniagua, and E. Vilaseca, $J$. Mol. Struct. (Theochem) 673 (2000) 87-92. 
50. M. Remko, P. D. Lyne, and W. G. Richards, Phys. Chem. Chem. Phys. 1 (1999) 5353-5357.

51. L. Senthilkumar and P. Kolandaivel, J. Mol. Structure 791 (2006) 149-157.

52. F. Ramondo, L. Bencivenni, V. Rossi, and R. Caminiti, J. Mol. Struct. (Theochem) 271 (1992) 185-211.

53. A. Jabalameli, N. U. Zhanpeisov, A. Nowek, R. H. Sullivan, and J. Leszczynski, J. Phys. Chem. A 101 (1997) 3619-3625.

54. N. Mora-Diez, M. L. Senent, and B. García, Chem. Phys. 324 (2006) 350-358

55. It should be mentioned that if the thermodynamic parameters for HU reported in Ref. 12 were inserted in Figure 9, the point would align much better to the theoretical line. However, the thermodynamic parameters defining the theoretical line in Figure 9 were determined by $\mathrm{pH}$ titration (taking $\mathrm{pH}$ measurements), whereas the kinetic measurements reported in Ref. 12 required the measurement of $\log \left[\mathrm{H}^{+}\right]$instead. For MetU the equilibrium measurements were impossible due to the high $\mathrm{p} K_{\mathrm{a}}$ value and the parameters from the kinetic measurements had to be considered instead.

56. C. P. Brink and A. L. Crumbliss, J. Org. Chem. 47 (1982) 1171-1176.

57. C. P. Brink and A. L. Crumbliss, Inorg. Chem. 23 (1984) 4708-4718.

58. C. P. Brink, L. L. Fish, and A. L. Crumbliss, J. Org. Chem. 50 (1985) 2277-2281. 